\title{
Reconstruction of the last cretaceous anoxic event in the Tarfaya Laayoune basin (South of Morocco): Biostratigraphy and Paleoenvironment of the Oum Debaa Formation
}

\author{
Amine Bouwafoud, Abdelmajid Benbouziane, Touria Hssaida \& Mustapha Mouflih
}

Reconstruction of the last cretaceous anoxic event in the Tarfaya Laayoune basin (South of Morocco): Biostratigraphy and Paleoenvironment of the Oum Debaa Formation. - Acta Mus. Siles. Sci. Natur. 70: 73-123, 2021.

\begin{abstract}
The Tarfaya-Laayoune coastal basin developed in a stable passive margin, where sedimentation occurred in shallow bays. During the Late Cretaceous, bituminous and phosphatic series were deposited in the shallow depression such as Sebkha Oum Debaa. In this work, the age of these Cretaceous layers are refined using a palynological approach and their paleoenvironments are described using organic geochemistry. Based on quantitative and qualitative palynological analyses, the sediments revealed a rich and diverse dinoflagellate cyst assemblage (65 taxa); among them 9 important biostratigraphic markers: Andalusiella inflata, Andalusiella ivoirensis, Andalusiella mauthei, Cerodinium diebelii, Cerodinium speciosum, Dinogymnium acuminatum, Odontochitina porifera, Trichodinium castanea, and Trithyrodinium evittii. According to the reported stratigraphic dinoflagellate taxa distribution, an age range of late Campanian to early Maastrichtian is herein proposed for the Oum Debaa Formation. This biostratigraphy update has been correlated to the Tethyan and Sub-Boreal domains. On the paleoenvironmental level, geochemical proxies have displayed an anoxic lagoon depositional which is dominated by an intermediate climate between hot / humid and arid with an often low paleoproductivity regime which induces redox conditions.
\end{abstract}

Key words: Tarfaya-Laayoune Basin, Sebkha Oum Debaa, dinoflagellate cysts, upper Campanian, palynofacies.

\section{Introduction}

The Upper Cretaceous and Tertiary is generally characterized by a greenhouse climate, high atmospheric concentrations of $\mathrm{CO} 2$, high global mean temperatures, and high sea level (Littler et al. 2011; Föllmi 2012), but some cooling episodes were also recognized (Price et al. 1999). These conditions favoured the formation of organic-rich rocks, often characterized by supra-regional occurrence, which originated during oceanic anoxic events (OAEs) and/or episodes of environmental changes (Föllmi 2012).

Bituminous sedimentary series rich in potential petroleum sources are known from the Silurian-Devonian, Domerian, and Cenomano-Turonian periods in the Atlantic, Atlas, and Tethyan basins in Morocco (El Albani et al. 1999; Aquit et al. 2013, 2017; Arthur \& Natland 2011; Benalioulhaj 1991; Benalioulhaj \& Trichet 1990; Le Heron et al. 2008; Keller et al. 2008; Kolonic et al. 2002; Kuhnt et al. 2001, 2005; Lebedel et al. 2013; Lüning et al. 2004; Nzoussi et al. 2005; Rachidi et al. 2009; Sachse et al. 2011, 2014).

In North Africa, the Upper Cretaceous formations are dominated by continental shelf deposits; among them black shales rich in organic matter, indicating the development of anoxic conditions (Robinson and Engel 1993). These continental shelf environments have also been characterized by high sedimentation rates (El Ayyat 2015; El-Shafeiy et al. 2014, 2017; Grosheny et al. 2008; Hartwig et al. 2012; Lüning et al. 2004; Meinhold et al. 2013; Pletsch et al. 2001; Tourtelot 1979).

The bituminous formation is contemporaneous with the appearance of the phosphatogen window in this basin. The pioneer works of J. La Vina (1961) and J. Rios (1972) have discovered phosphates comparable to those already discovered in the Moroccan meseta. 


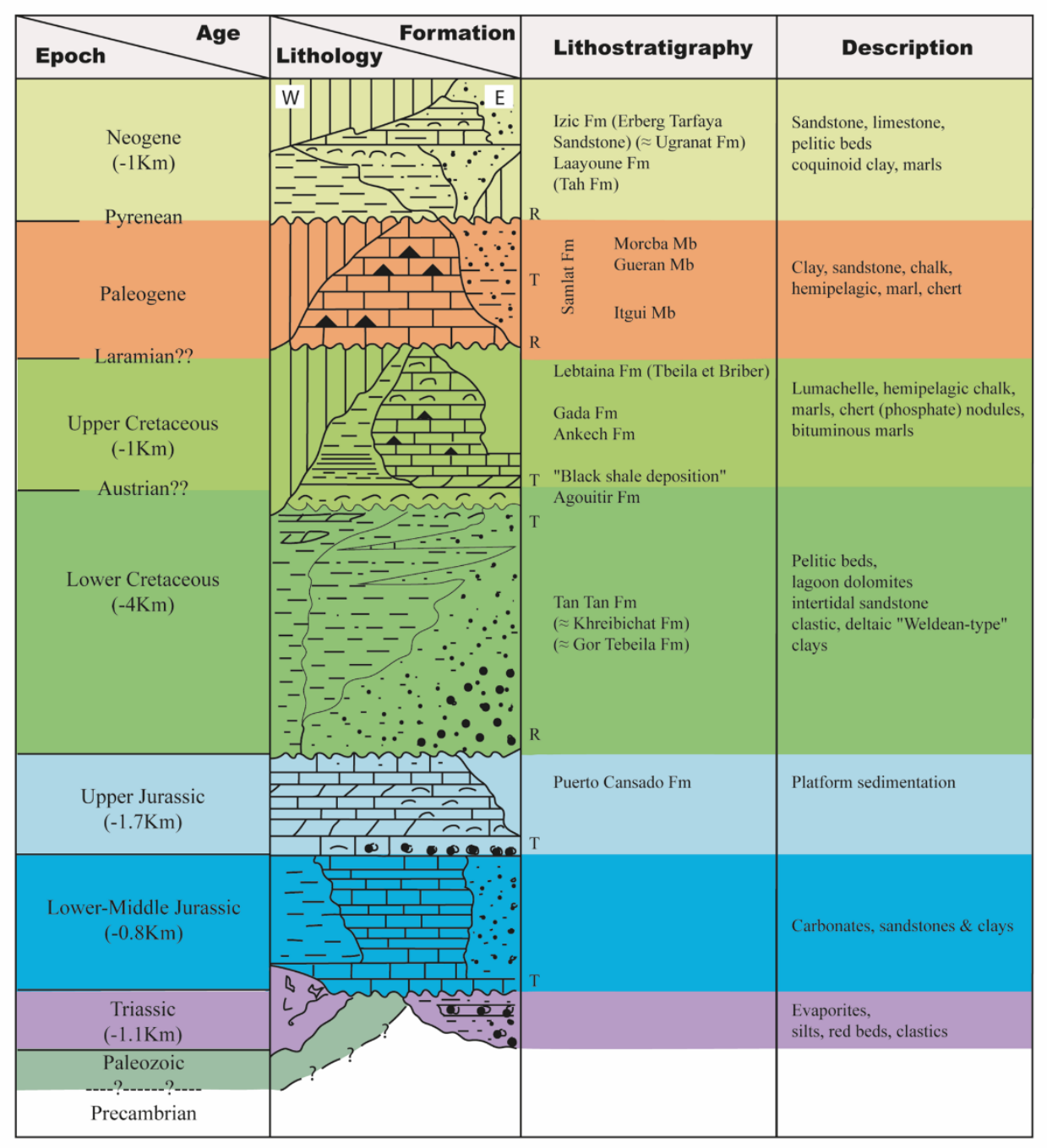

Legend

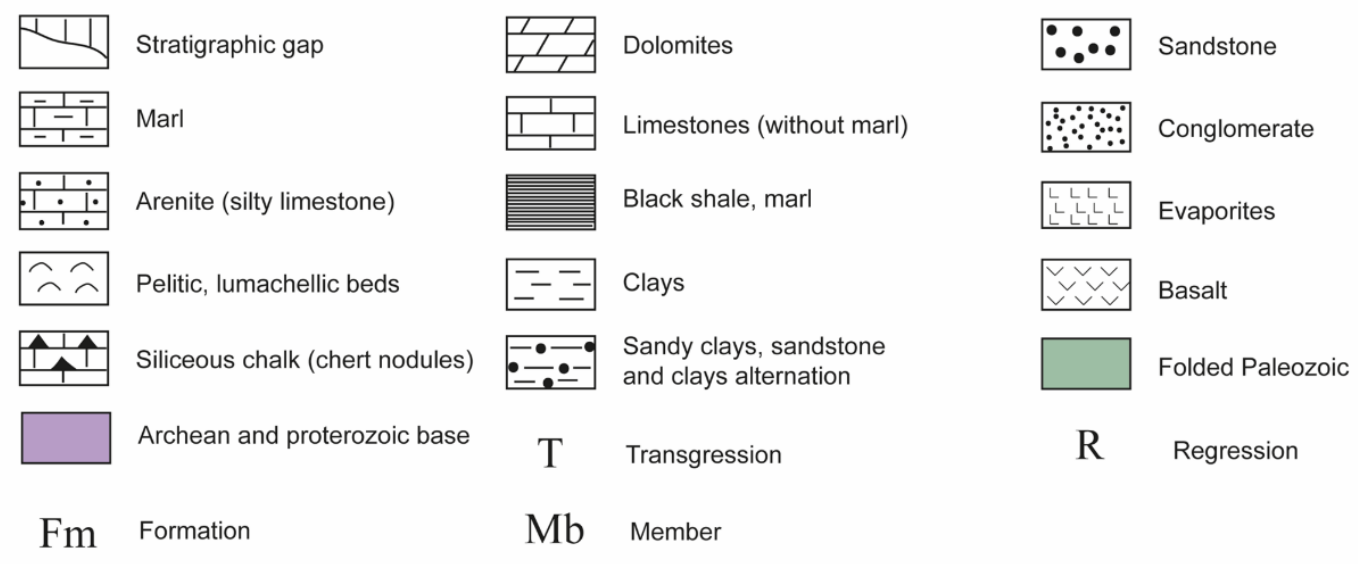

Fig 1: Lithostratigraphic synthesis of the Tarfaya-Laayoune basin according to Martinis and Visintin (1966), Choubert et al. (1960), Auxini (1969), Ratschiller (1970), Linder and Querol (1971), and petroleum exploration data (modified after Rjimati et al. 2009, 2011).

Its represents an important gulf quiet and independent from the other basins; it's known as "Tarfaya-Dakhla gulf". Recently, Nguidi et al. (2021) provide some answers and suggest that these deposits accumulated in a shallow oxygenated plateau environment initially formed in an anoxic environment during a Highstand system tract. 
In this study, we focus on Cretaceous bituminous sedimentation of the Oum Debaa Formation in southern Morocco which is well-developed in the coastal basin of TarfayaLaayoune-Dakhla (Abioui et al. 2019; Ali et al. 2019; Beil et al. 2018; Benammi et al. 2019; Fabre et al. 2018; Ghassal et al. 2016; Lebedel et al. 2015; Meister et al. 2017; Prauss 2015; Zouhri et al. 2018, 2014).

Here our main objective is to date with biostratigraphy the bituminous sediments of the Oum Debaa Formation in the Laayoune basin located between Tarfaya and Laayoune. The present work aim to restudy the final stage of the sedimentation of organic-rich rocks from the Oum Debaa formation outcropped around the Laayoune region (southwest of Morocco) based on Dinoflagellate cysts. Other aims are to provide new data for the cartography of the region and to characterize the type of organic matter constituting the bituminous facies of the investigated section. In addition, based on the obtained results reconstruction of ancient depositional environments is attempted.

\section{Geological setting}

The Tarfaya-Laayoune-Dakhla Basin, a coastal basin that developed in a stable passive margin, is located in the NW region of the Archean-Proterozoic ridge of the Reguibate Domain /i.e., NW of the West African craton, see Rjimati et al. (2011). The basin is bordered by the Proterozoic Anti-Atlas Domain, the Paleozoic-Cenozoic Tindouf Basin to the N and NE, and the Archean and Proterozoic crystalline massifs of the Tiris Domain to the E. At the S-SE edge, the basin is linked to the Archean and Proterozoic crystalline massifs of the Oulad Dlim Domain, which were affected by the Hercynian orogenic phase.

The Precambrian and Paleozoic basement is composed of very complex structures divided into horsts and grabens. These structures are filled by Liassic syn-rift sequences which are essentially composed of red clastic sediments comprising conglomerates, sandstones, and shales. In the grabens, dolerite are interbedded within these deposits.

During the Cretaceous, sedimentation occurred only in shallow depressions, known as sebkhas. The studied region belongs to one such depression, called Sebkha Oum Debaa. Regarding the overall stratigraphy of the onshore portion of the Tarfaya-Laayoune Basin (Fig. 1), the Upper Cretaceous deposits display a complete succession attributed to different lithostratigraphic units, described as follows in chronological order from the bottom to the top:

1) The Turonian and Cenomanian deposits are attributed to the Marnes d'Oued Chbeika Formation (Choubert et al. 1966) and also to the Ankech Formation (Lindner \& Querol, 1971).

2) The Campanian, Santonian, and Coniacian deposits belong to the Marnes d'Oued Khaoui Naam Formation (Choubert et al. 1966) and Gada Formation (Geological map of the Northern Spanish Sahara 1:200 000, sheet 15, Spanish Geological and Mining Institute).

3) The Campanian deposits are also partly associated with the Gada Formation (Lindner \& Querol, 1971), with further parts belonging to the Oum Debaa Formation (Rjimati et al. 2002; Rjimati \& Zemmouri 2009).

4) The Maastrichtian deposits are associated with the Lebtaina Formation (also known as the Tbeila Formation or Briber Formation) (Ratschiller 1970) and consist of marls intercalated with siliceous and/or phosphatic chalk. 
Table 1: Correlations of Meso-Cenozoic lithostratigraphic units in the Tarfaya Laayoune basin (modified after Rjimati et al. 2011).

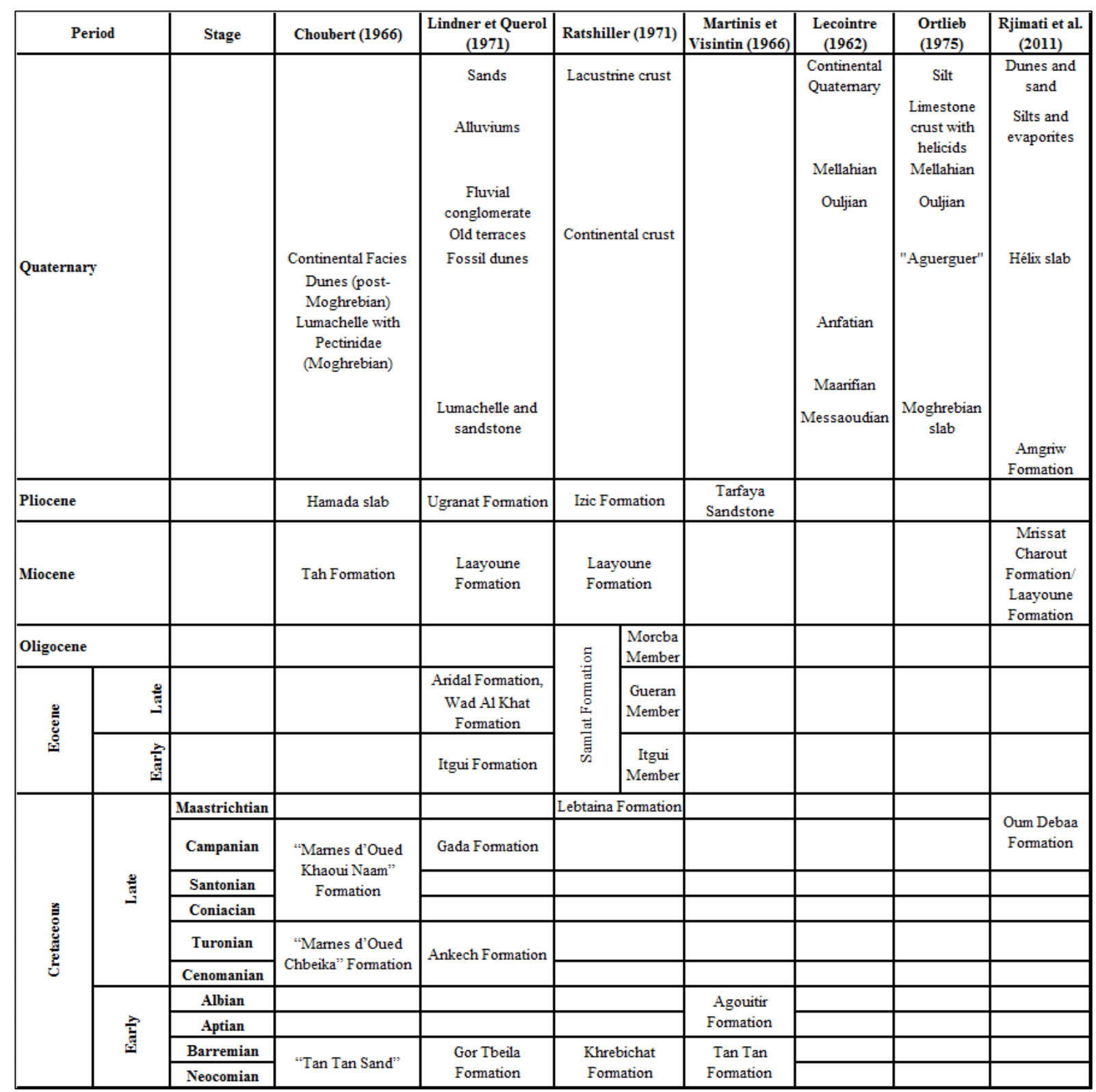

Table 1 outlines the debate that occurs in the assignment of lithostratigraphic units and formation names. A marked erosional truncation can be observed offshore in the northwestern part of the basin between the town Tarfaya at Cape Juby and Cape Boujdour (Daoura 1-1 borehole, site 397). At this location, part of the Early Cretaceous, Late Cretaceous, and Paleogene sediment covers have been eroded (Rad \& Wissmann 1982).

The Sebkha Oum Debaa shallow depression (Fig. 3) is a morphological relief typical of arid regions. Typical sebkhas are closed depressions with impermeable bases and indicate arid conditions in which aeolian and evaporative processes mainly contribute to their formation. Arid regions are often located inland or centripetal to drainage areas, and globally tend to occur in deserts below sea level (Goudie 2013). Sebkha Oum Debaa is no exception, at $11 \mathrm{~m}$ below sea level, and is the smaller western extension of the larger Sebkha Tah (55 m below sea level). Sebkha Oum Debaa formed on a plain lying between land and sea. In our study, these characteristics are useful for studying the overlying formations in the outcrops, especially since the peneplain topography of the Sahara Desert makes such research difficult. 


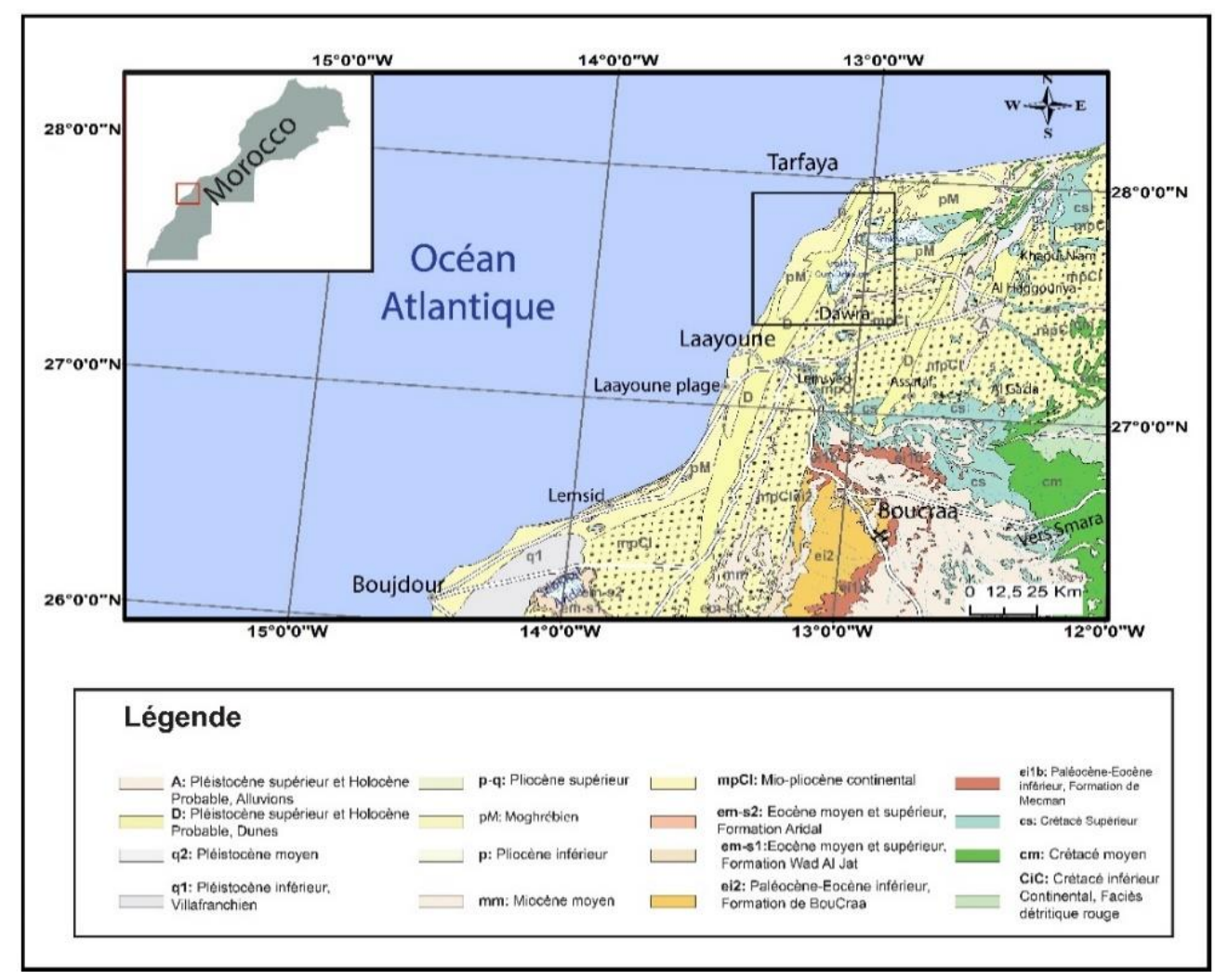

Fig 2: Geological Map of the Tarfaya-Laayoune basin (source: the geological map of Morocco 1.1000000) and the studied area has been surrounded by a black frame.

\section{Materials and methods}

\section{Location of the studied section}

The studied section is located in the NE edge of sebkha Oum Debaa (N 27²8'47.833" / W 12 59'22.969'). It is located $35 \mathrm{~km}$ north of the city of laayoune and $5 \mathrm{~km}$ from the center of Deroua (Fig. 3).

\section{Palynology}

Eight Cretaceous samples (samples 1-8, Tab. 2) were collected from the studied section and treated according to the standard palynological techniques (Wood et al. 1996; Traverse 2007).

All palynological slides are stored in the palynology laboratory, Ben M'sik Faculty of Sciences (Hassan II University of Casablanca-Morocco). In this work, the paleoenvironment reconstitution has been performed according to the Tyson's method $(1993,1995)$ which considers three parameters: phytoclasts, palynomorphs and amorphous organic matter (AOM). These parameters expressed in a ternary diagram subdivided into ten fields which decipher the environment deposit and the related kerogen type.

All dinocyst taxa identified in this study are listed in alphabetical order in the species list. The England Finder (EF) coordinates of the specimens shown are given in the legends on the plates (see pages 89-91).

\section{Geochemistry}

Concerning the major and trace element geochemistry of the sediments, the samples were analyzed with Inductively Coupled Plasma Mass Spectrometry ICP-MS (the sample preparation method complies with Standard BS EN 13346, which describes the method for extracting trace elements and phosphorus in sludge and solids with aqua regia), but only elements related to a proxy for depositional conditions are shown in this study. 


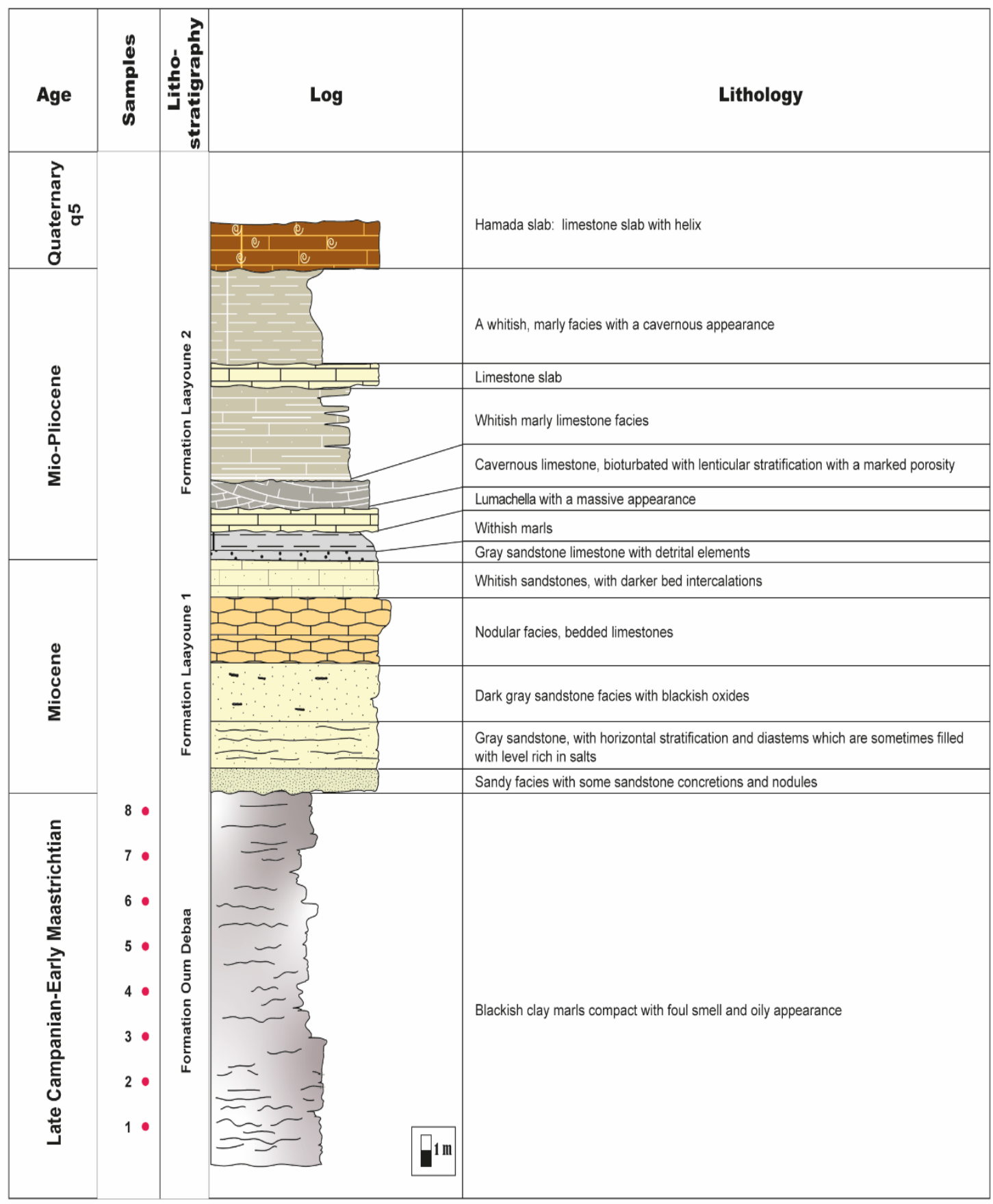

Fig 3: Lithostratigraphy and lithology of the type section of Oum Debaa Formation in Sebkhat Oum Debaa and related overlying Cenozoic rocks. 

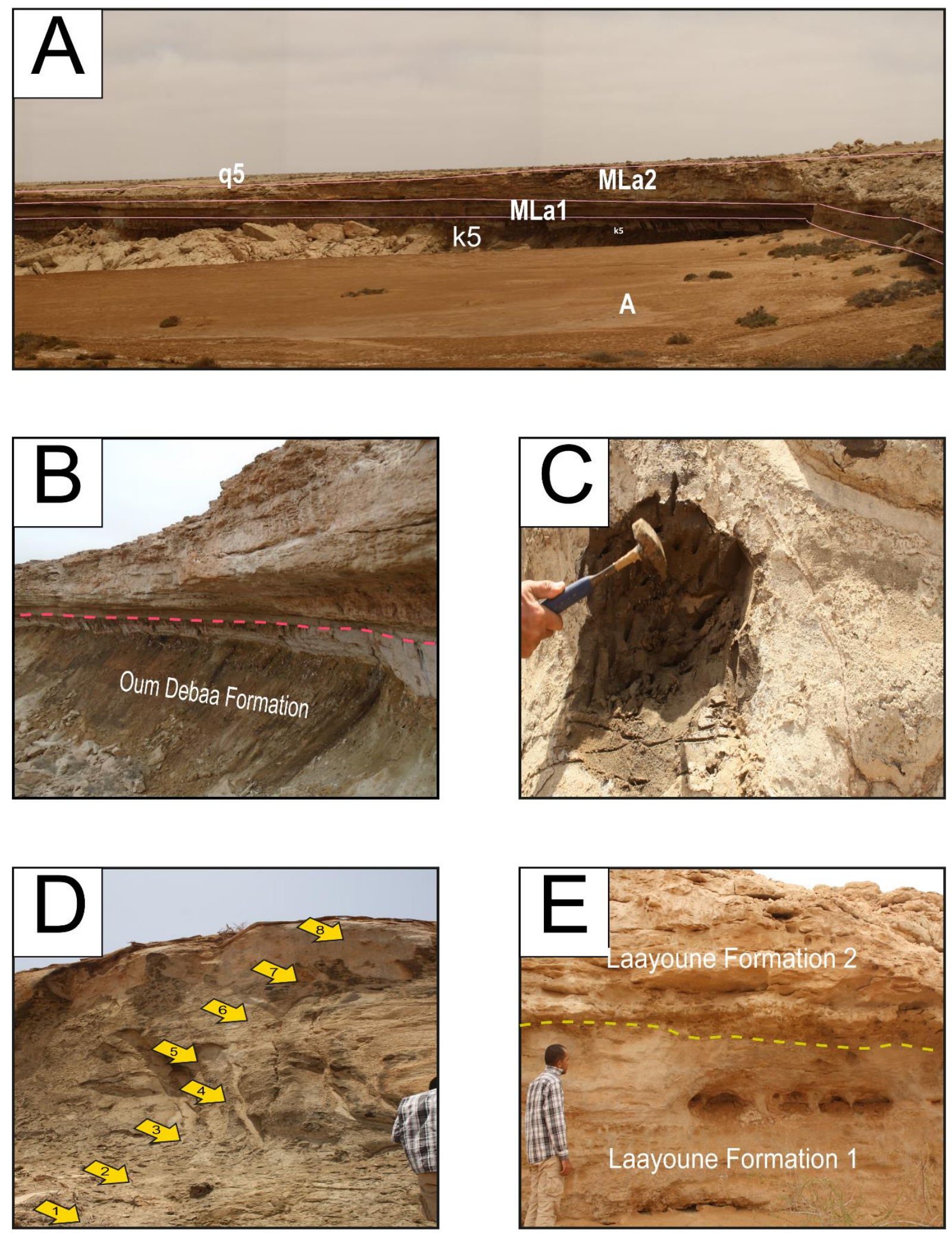

Fig 4: A - Panoramic view of all formations in the Oum Debaa section; $\mathrm{k} 5$ = Oum Debaa Formation (Late Cretace-ous), MLa1 = Laayoune 1 Formation (Miocene), MLa2 = Laayoune 2 Formation (Mio-Pliocene), $\mathrm{q} 5=$ Hammada slab; B - The erosional truncation between the Oum Debaa Formation and the sandstone and Cenozoic carbonate formations; C - Close-up on the bituminous facies. Note the blackish color and oily appearance; D - Location of collected samples; $\mathbf{E}$ - The passage between the Laayoune 1 Formation, which primarily presents sandstone facies and the Laayoune 2 Formation of the Mio-Pliocene age, which mainly shows carbonate or marly facies. 
Table 2: Organic matter and palynofacies characterizations of the Campanian Bituminous marly facies from the Oum Debaa Formation. Note that the TOC content ranges between 0.51 and $4.67 \%$.

\begin{tabular}{|c|c|c|c|c|c|}
\hline Samples & Organic Matter & Description of organic matter & Preservation & Maturity & Kerogen type \\
\hline OD8 & $\begin{array}{l}\text { AOM (30\%) } \\
\text { Phytoclasts (15\%) } \\
\text { Palynomorphs } \\
(55 \%), \\
\text { predominated by } \\
\text { dinoflagellate cysts }\end{array}$ & $\begin{array}{l}\text { Golden yellow amorphous organic } \\
\text { matter in the form of granules. } \\
\text { Phytoclasts are common and } \\
\text { dinoflagellate cysts are very abundant } \\
\text { and diverse. Some rare pollens and a } \\
\text { very good representation of } \\
\text { Palambages. }\end{array}$ & Good conservation & Post-mature & III \\
\hline OD7 & $\begin{array}{l}\text { AOM (65\%) } \\
\text { Phytoclasts (5\%) } \\
\text { Palynomorphs } \\
(30 \%) \\
\end{array}$ & $\begin{array}{l}\text { Amorphous organic matter is very } \\
\text { abundant in the form of clumps and } \\
\text { brown in color, masking the } \\
\text { palynomorphs. Spores and pollens are }\end{array}$ & Good conservation & Immature & II \\
\hline OD6 & $\begin{array}{l}\mathrm{AOM}(50 \%) \\
\text { Phytoclasts (5\%) } \\
\text { Palynomorphs } \\
(45 \%)\end{array}$ & $\begin{array}{l}\text { Sparse brown amorphous organic } \\
\text { matter in the form of field or granules. } \\
\text { Phytoclasts are rare, some } \\
\text { spore/pollens, foraminifera and a very }\end{array}$ & Good conservation & Immature & II \\
\hline OD5 & $\begin{array}{l}\text { AOM (64\%), } \\
\text { Phytoclasts (2\%) } \\
\text { Palynomorphs } \\
(34 \%)\end{array}$ & $\begin{array}{l}\text { Marine amorphous organic matter in } \\
\text { the form of field or climps, dominant } \\
\text { (masking the palynomorphs). } \\
\text { Dinoflagellate cysts are common and }\end{array}$ & Good conservation & Immature & II \\
\hline OD4 & $\begin{array}{l}\text { AOM }(60 \%) \\
\text { Phytoclasts } \\
(2.5 \%) \\
\text { Palynomorphs } \\
(37.5 \%) \\
\end{array}$ & $\begin{array}{l}\text { Amorphous organic material of } \\
\text { marine origin as clumps or field, } \\
\text { uniform, and dark in color. } \\
\text { Phytoclasts are rare. Cysts are } \\
\text { abundant with rare pollens, }\end{array}$ & Good conservation & Immature & II \\
\hline OD3 & $\begin{array}{l}\text { AOM (62\%) } \\
\text { Phytoclasts (5\%) } \\
\text { Palynomorphs } \\
(33 \%)\end{array}$ & $\begin{array}{l}\text { Sparse amorphous organic matter, in } \\
\text { the form of a darkfield. Dinoflagellate } \\
\text { cysts are common with a few } \\
\text { foraminifera, pollens, and algae. }\end{array}$ & Good conservation & Immature & II \\
\hline OD2 & $\begin{array}{l}\text { AOM (70\%) } \\
\text { Phytoclasts (0\%) } \\
\text { Palynomorphs } \\
(30 \%)\end{array}$ & $\begin{array}{l}\text { Very dark marine amorphous organic } \\
\text { matter in the form of dark } \\
\text { accumulation or clumps. Absence of } \\
\text { Phytoclasts. Dinoflagellate cysts are } \\
\text { masked by the dense AOM, and }\end{array}$ & $\begin{array}{l}\text { Very Good } \\
\text { conservation }\end{array}$ & Immature & II \\
\hline OD1 & $\begin{array}{l}\text { AOM (60\%) } \\
\text { Phytoclasts (0\%) } \\
\text { Palynomorphs } \\
(40 \%)\end{array}$ & $\begin{array}{l}\text { Amorphous organic matter in the } \\
\text { form of clumpsor field, well-preserved } \\
\text { dark brown color. Phytoclasts are } \\
\text { absent. Dinoflagellate cysts }\end{array}$ & $\begin{array}{l}\text { Very Good } \\
\text { conservation }\end{array}$ & Immature & II \\
\hline
\end{tabular}

\section{Results}

\section{Lithostratigraphy}

The base of the section (Fig. 3) contains Late Cretaceous compacted marl that is generally grayish on the surface and appears greenish and dark when fresh; its color is dependent on the content of organic matter. Overall, the formation presents an oily appearance, generating a visibly bituminous, monotonous series along the length of the outcropped formation.

This study exclusively highlights the bituminous formation at the point where its maximum thickness does not exceed $10 \mathrm{~m}$ in the studied zone. In the outcrop, the contact between the Coniacian and Campanian deposits is not visible; further, the transition between the bituminous sedimentation and the overlying formations is marked by an angular discordance which has eroded all of the Paleogene formations in the northwestern part of the Tarfaya Laayoune Dakhla Basin.

Above the Oum Debaa Formation, the lithological succession displays in the following order from the base to the top (Fig. 4): 
1) Sandy facies with some concretions and nodules of grayish brown sandstone;

2) Levels of meter-thick gray sandstone facies. This interval is horizontally stratified with diastems, which are sometimes filled with salt-rich layers;

3) A sedimentary Miocene-Pliocene cycle, essentially consisting of limestone alternating with whitish marls;

4) A limestone slab at the top containing terrestrial fossils (e.g., Helix) deposited during the Moghrebian time period (Quaternary - q5). It should be noted that, currently, discrepancies exist about the precise stratigraphic age, being considered either Pliocene (Lecointre 1949), or Quaternary (Choubert 1946). The Moghrebian sediments are calcareous sandstone, appearing as an erosion-resistant slab with an average thickness of $\sim 20 \mathrm{~m}$ (Brebion \& Ortlieb, 1976).

\section{Geochemical characteriation}

The main oxides identified in the samples are dominated mainly by $\mathrm{CaO}$ and $\mathrm{SiO} 2$, followed by $\mathrm{A} 12 \mathrm{O} 3, \mathrm{MgO}, \mathrm{Na} 2 \mathrm{O}$, while the concentration of the other oxides is generally low $(<1 \%)$. The $\mathrm{CaO}$ contents vary from 16.38 to $27.55 \%$, while the $\mathrm{SiO} 2$ concentrations range between 12.21 and $21 \%$. The variation of these major oxides concur with sedimentological observation such as the bituminous shale has expected higher $\mathrm{Si}$ and $\mathrm{Al}$ content versus bituminous limestone with relatively higher $\mathrm{Ca}$ content. The generally low $\mathrm{MgO}$ may reflect only minute proportions of dolomite in the carbonate fraction.

In terms of trace elements, they yielded, in decreasing order, the following median values: Sr (354), V (141), Cr (134), Mo (37), U (22), Th (6). Except Sr, the analyzed trace elements are redox sensitive and hence can help tracing redox conditions in the depositional environment.

In the study series, TOC content mostly ranged from $2.85-4.67 \mathrm{wt} . \%$ Which indicates a medium to high organic matter content. on the other hand, the top of the series indicates lower values in TOC not exceeding 0.51 wt. $\%$.

\section{Biostratigraphy}

The palynological material recovered after treating the samples shows exceptional richness in the palynomorphs comprising spores and pollen, acritarchs, primitive foraminifera, and algae including Palambages and dinoflagellate cysts, of which the latter predominates among the palynomorphs with a proportion ranging from $80-95 \%$. The dinoflagellate cyst assemblages are highly rich, diverse, and in an excellent preservation state. A total of 65 taxa were identified from the eight samples. The distribution of the species along the studied section is illustrated in Fig. 5.

Samples from the studied section display an association dominated by the genera Odontochitina spp. and Trichodinium spp. in its lower part (between the base and location of sample 4). The genera Spiniferites spp. and Alterbidinium spp. Also show high rates along the section (over 50\% in some samples). The genera Andalusiella spp., Trithyrodinium spp., and Dinogymnium spp. show good representativeness, particularly in the upper part of the section (between the locations of samples 4 and 8). Other taxa, listed in our associations, are rarely noted, such as Thalassiphora pelagica (single specimen, sample 8) and Senoniasphaera inornata (single specimen, sample 6). 


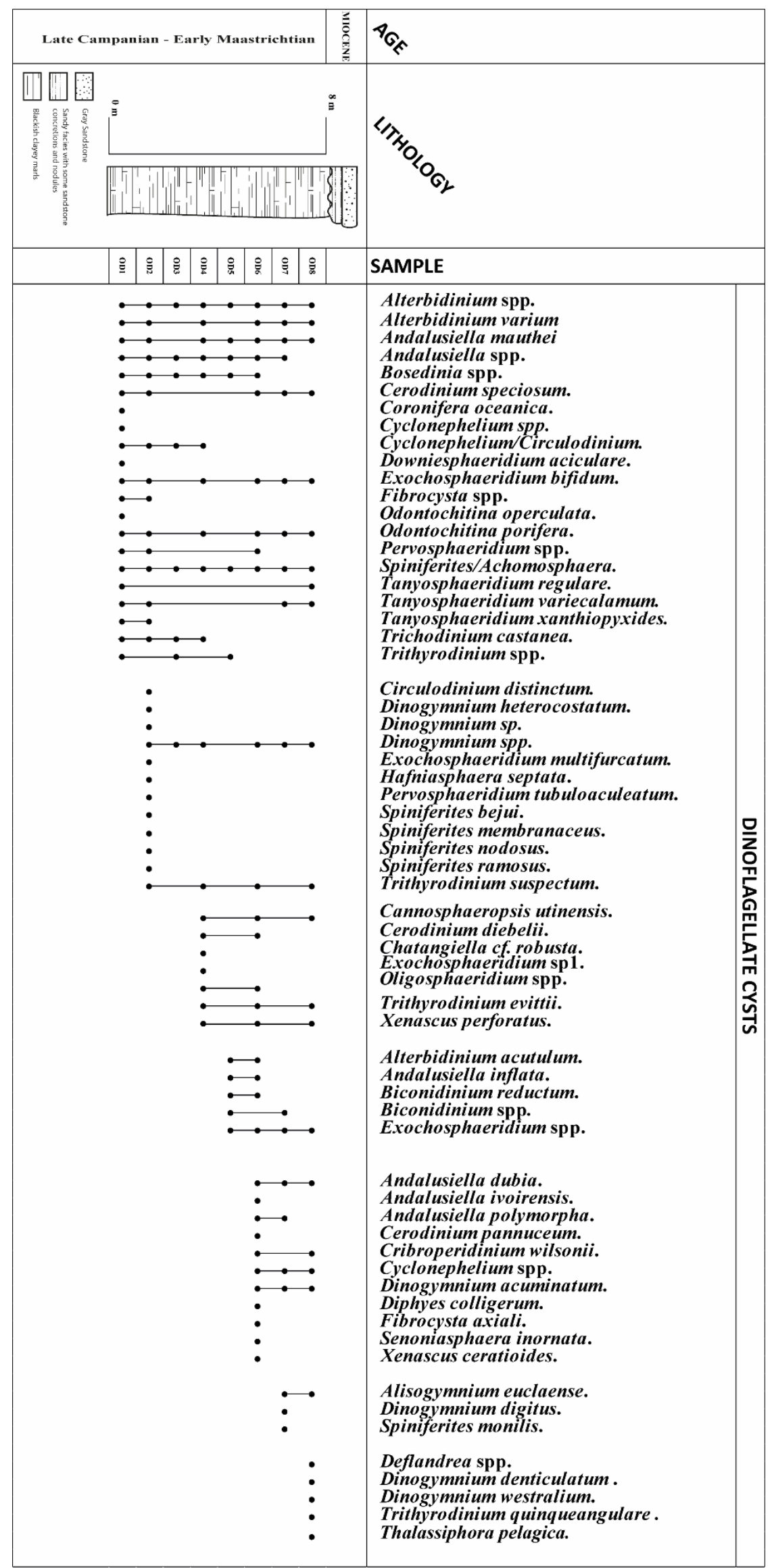

Fig 5: Stratigraphic range chart of the dinoflagellate cysts species identified in the Oum Debaa section. 
From the bottom of the section (sample 1), we identified the coexistence of two taxa that show stratigraphic significance, even at the genus level: Areoligera spp. and Andalusiella spp. The First Occurrence (FO) of Areoligera did not occur before the Campanian (Bujak and Williams 1985; Williams et al. 2004) but was recorded in the Campanian at sites in Gabon, West Africa (Boltenhagen 1977) and at Tercis les Bains (Global Standard-stratotype Section and Point for the Campanian-Maastrichtian boundary, Masure 1985), as well as in the Campanian strata of New Jersey in the United States (Aurisano 1989). The Andalusiella group is well-known in the Campanian strata of Gabon (Boltenhagen 1977) and Egypt (Schrank 1987).

In the strata of this study, these two taxa are common, starting at the base of the section (sample 1), together with the following species: Andalusiella mauthei, Cerodinium speciosum, Odontochitina operculata, Odontochitina porifera, and Trichodinium castanea. Trichodinium castanea has a wide stratigraphic distribution (Barremian-Campanian) (Premaor et al. 2010), but its Last Occurrence (LO) is located in the early Maastrichtian throughout the Northern Hemisphere (Fensome \& Williams 2004). Its association with C. speciosum, O. operculate, and $O$. porifera at the base (sample 1) indicates that this part of the section cannot be older than the late Campanian. Indeed, the C. speciosum FO is located in the late Campanian both at high latitudes, such as in strata of Canada (Kurita \& McIntyre 1995; McIntyre 1999) and the Antarctic (Smith et al. 1992), as well as strata in the mid-latitudes (Beilstein 1994).

In most regions, the species $O$. operculata has as broad stratigraphic distribution as T. castanea; its LO is recorded in strata of the lower Campanian (Razmjooei et al. 2018); however, in France in the Tercis-les-Bains region its LO is in the late Campanian (Antonescu et al. 2001a; 2001b). This species has been even used to characterize strata of the Campanian in northern Egypt (Ela et al. 2019). The Tercis-les-Bains area is correlated with Zone II deposits in NW Egypt (Schrank \& Mia, 1995), which belong to the Campanian-Maastrichtian age. However, in Morocco, O. operculata is detected until the early Maastrichtian (Rauscher \& Doubinger, 1981).

Coupled with this species, we also identified the abundance and dominance of the species O. porifera, with a prevalence of $31.85 \%$ among the discovered dinoflagellate cysts. This species has a distribution from the Santonian to the Campanian (Premaor et al. 2010), and its LO coincides with the early Maastrichtian (Williams et al. 2004) in both the Northern and Southern hemispheres. This evidence argues for a strata age which is no older than the late Campanian.

Between the samples 1 and 4, we found simultaneous or progressive occurrences of other taxa. In sample 2, we identified simultaneous FOs of several taxa, including Exochosphaeridium multifurcatum and several species of the genus Spiniferites, including $S$. bejui, S. fluens, S. membranaceus, $S$. nodosus, S. ramosus, and S. septatus.

The latter genus generally has a wide stratigraphic distribution, though its FO is in the Campanian (May, 1980). However, the presence and dominance of these species within the present studied section (51\% of all dinoflagellate cysts) could have ecological significance. This is because all Spiniferites species have a wide stratigraphic distribution except $S$. fluens, which is of stratigraphic interest since it has never been recorded in sediments younger than the early Maastrichtian (Stover et al. 1987; Kirsch, 1991; Habib et al. 1994; Helenes, 1998; Masure et al. 1998; Oboh-Ikuenobe et al. 1998).

Other appearances are progressive; for example, the FO of Trithyrodinium evittii characterizes a biozone, corresponding to the late Campanian of Tercis-les-Bains (Antonescu et al. 2001a, 2001b). In sample 4, the LO of Trichodinium castanea occurs with the FOs of the following taxa: Alterbidinium acutulum, Andalusiella inflata, Cannosphaeropsis utinensis, Cerodinium diebelii, and Xenascus ceratioides. This evidence reinforces that the strata of the lower part of the section (between samples 1 and 4) belong to the late Campanian. 
However, the LOs of T. castanea and the FOs of C. diebelii are in line with the world distribution maps of Williams and Bujak (1985), which suggest a Campanian age. However, C. diebelii is a better marker for the base of the Maastrichtian according to Antonescu et al. (2001b) but its optimal occurrence (OC) have been verified in the late Campanian (Antonescu et al. 2001a, 2001b; Slimani 2001a, 2001b; Slimani et al. 2011). In addition, C. diebelii is a cosmopolitan species; even at higher latitudes, it has been identified in the CampanianMaastrichtian interval in Canada and Greenland deposits (Ionnides, 1986; Nøhr-Hansen, 1996), the mid-latitudes (Lentin \& Williams 1985; Masure et al. 1998; Oboh-Ikuenobe et al. 1998), and Antarctica (Pirrie et al. 1997; Riding et al. 1992).

Between samples 4 and 8, the associations are enriched with Maastrichtian-affinity taxa, such as Alterbidinium acutulum, Andalusiella inflata, Andalusiella ivoirensis, Cannosphaeropsis utinensis, Dinogymnium acuminatum, and Trithyrodinium quinqueangular. The taxon $C$. utinensis can be distributed from the late Santonian to the late Maastrichtian (Begouën et al. 1990; Williams et al. 2004; Radmacher et al. 2014), and is typically found in association with Maastrichtian-affinity taxa, such as the species Alterbidinium acutulum (early Maastrichtian) ( Antonescu et al. 2001a, 2001b; Nøhr-Hansen 2012; Slimani 2001a, 2001b; Slimani et al. 2011), Alterbidinium minus (lower Maastrichtian) (Antonescu et al. 2001a, 2001b; Kjellström 1973; Slimani et al. 2011; Soncini and Rauscher 1988; Wilson 1971), Alterbidinium varium (early Maastrichtian) (Kirsch 1991; Slimani 1995, 2001b; Slimani et al. 2011), Andalusiella inflata (Lentin \& Williams 1985; Masure et al. 1996; Soncini \& Rauscher 1988), Andalusiella ivoirensis (Maastrichian) (Masure et al. 1996, 1998), and Trithyrodinium quinqueangulare (early Maastrichtian) (Antonescu et al. 2001a, 2001b; Lentin 1993; Marheinecke 1992).

Within this association of highly rich and diverse dinoflagellate cysts, the top of the section is marked by the presence of two species: Senoniasphaera inornata, which is common in both the Northern and Southern hemispheres (Williams et al. 2004), and Thalassiphora pelagica (Habib et al. 1996; Stover et al. 1996; Roncaglia \& Corradini, 1997; Oboh-Ikuenobe et al. 1998; Brinkhuis et al. 2003; Landman et al. 2004). Both species' FOs are in the Maastrichtian, but their LOs are in the Cenozoic. Thereby, we raise the question: does the presence of these species indicate an early appearance in Morocco or is it related to a reworking phenomenon associated with the nature of the sediment deposition?

Overall, the palynological analysis of the sediments in the Oum Debaa Formation shows enrichment of dinoflagellate cysts dominated by the genus Spiniferites, a phenomenon which has already been observed in upper Campanian sediments of Iran (Razmjooei et al. 2018). It should be noted that organisms in the Tethyan domain typically associated with this time interval, whether from Iran (Razmjooei et al. 2018) or Egypt (El Beialy et al. 2010; Ela et al. 2019; Schrank 1987; Tahoun et al. 2018; Tahoun \& Ied 2019), are commonly not rich in dinoflagellate cysts. In Morocco, the wealth cysts (Rauscher \& Doubinger 1981; Soncini \& Rauscher 1988; and this work) is more similar to those observed in NW Europe (Antonescu et al. 2001a, 2001b; Radmacher et al. 2014; Slimani 2001a, 2001b; Slimani et al. 2011) and Latin America (Garzon, Warny \& Bart 2012).

In correlation with other paleogeographic domains, $C$. speciosum, T. castanea, O. porifera, $D$. acuminatum, and $C$. diebelii characterize well the late Campanian-early Maastrichtian interval. In fact, C. diebelii identifies the Campanian-Maastrichtian passage (Antonescu et al. 2001; a, 2001b) and coincides with the presence of three genera Alterbidinium, Isabilidinum, and Manumiella, which collectively constitute an event of the Campanian-Maastrichtian transition in NW Europe (Antonescu et al. 2001a, 2001b). These genera are common along the studied section, and with notable frequencies.

The attribution of the late Campanian-early Maastrichtian age in the studied outcrop of the Oum Debaa Formation is also supported by the presence of the species D. acuminatum, 
which constitutes a zone that is consistent with the Campanian-Maastrichtian interval in Egypt (El Beialy, 1995; Schrank \& Mia, 1995). Further support is owing to the presence of A. mauthei, which is present along the section and is the dominant species, among other species of the same genus (i.e., Andalusiella spp.). The FO of this species is found within deposits of the Senonian (Riegel \& Sarjeant, 1982; Masure et al. 1996), but its OC is in the CampanianMaastrichtian interval (Masure et al. 1998; Tea-Yassi et al. 1999; Yepes 2001).

The taxa associations (A. inflata, A. acutulum, A. varium, A. minus, A. ivoirensis, and T. quinqueangular) and the markers of the early Maastrichtian in the studied sediments of the Oum Debaa Formation reinforces the late Campanian-early Maastrichtian age in this section.

\section{Palynofacies}

Using the Tyson method (1993, 1995), 300 particles of the main constituents of palynofacies (i.e., phytoclasts, palynomorphs, and AOM) were counted and an associated ternary diagram was produced (Fig. 6), illustrating the distribution of the samples according to their depositional environments, including the indication of redox conditions. In addition to determining the redox conditions in the basin, the three main constituents were evaluated for association with one of the four types of kerogens (type I , II, III, or IV) (Harwood 1977; Tissot \& Welte 1984; Tyson 1995).

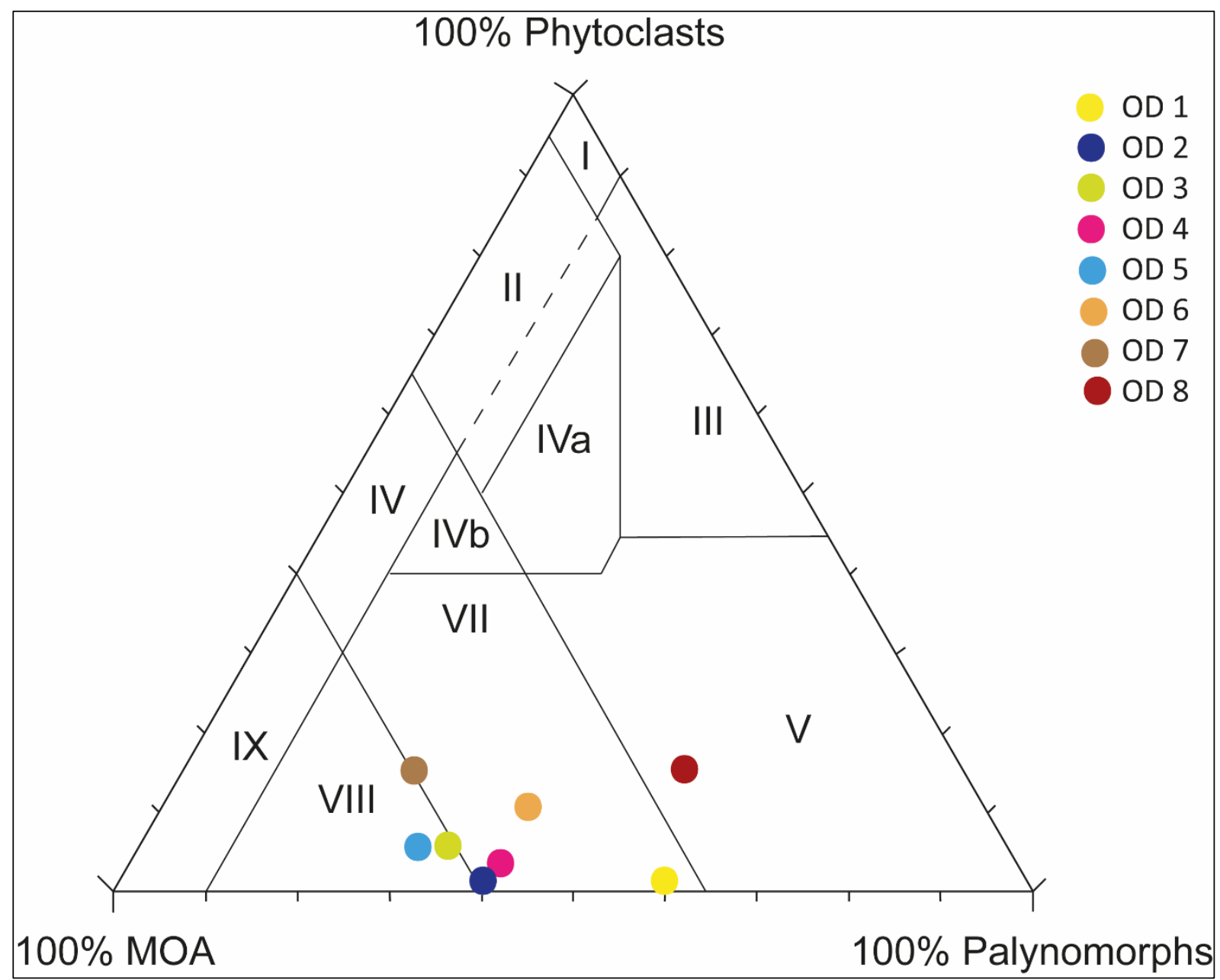

Fig 6: Tyson-type ternary diagrams showing distribution of principal palynological groups for the studied samples in the Oum Debaa section. 
Counted phytoclasts included translucent phytoclasts (e.g., wood cuticles), referring to all plant particle structures of yellow to brown color, and opaque phytoclasts (equidimensional or elongated), referring to all plant particles that are oxidized or charred, of black to brownish color, and structured or derived from kerogen. Counted palynomorphs included all structured organic microfossils resistant to strong acids (e.g., spores, pollens, acritarchs, primitive foraminifera, and dinoflagellate cysts or other related compounds).

\section{Discussion}

\section{Origin and maturation of organic matter}

The interaction of the three palynofacies components in the Oum Debaa Formation sediments suggest two types of paleoenvironments based on the Tyson ternary diagram (Fig. 6):

First, Samples 1 to 7, which are located between fields VII and VIII on the ternary diagram, correspond to a distal platform with anoxic to dysoxic redox conditions (see Tyson, 1993, 1995), with AOM in the form of clumps or tufts or as well-structured, well-preserved resin. The palynomorphs are dominated by dinoflagellate cysts covered by AOM. The terrigenous fraction (i.e., spores, pollens, and phytoclasts) is rare. The abundance and dominance of this AOM, which occupied between $50-70 \%$ of the total palynofacies, is the consequence of a low energy environment, which is also an indicator of anoxic-dsyoxic conditions (Tyson 1993, 1995) and is in agreement with similar findings by Koleif and Ibrahim (2010). In this interval, the dinoflagellate cysts associated are characterized by the presence and abundance of peridinoid cysts, which do not only tolerate fluctuations in salinity, but also seem to thrive in relatively nutrient-rich environments, such as shallow marine areas or upwelling regions (Bujak, 1984; Dale \& Fjellså, 1994; Eshet et al. 1994; Lewis et al. 1990; Powell et al. 1990). The intense paleoproductivity indicated by the Oum Debaa Formation could be linked to the upwelling cell that has been active at the level of the Moroccan Atlantic margin since the upper Cenomanian (Einsele \& Von Rad, 1979; Einsele \& Wiedmann, 1982; Kuhnt \& Moullade, 1991; Prauss, 2015). The same conditions have already been observed by Eshet et al. (1994), who pointed out an abundance of peridinoids in AOM-rich sediments in the Zin and Shfela basins under the influence of upwellings during the Late Cretaceous period (Campanian to Maastrichtian) (Almogi-Labin, Bein, and Sass 1993). For this type, the main organic source comes from phytoplankton, with subordinate zooplankton and occasional important contributions from benthic algae. A predominance of marine organic matter may also be provided by generalized transgressions creating shallow epicontinental seas with high biological productivity. This situation was probably more common during certain conducive geological periods, for example, as indicated by the Cretaceous black shales of the Atlantic basins (Tissot \& Welte, 1984). Moreover, planktonic organic matter is generally found in areas of relatively high productivity where conservation of such organic matter was ensured by the anoxic or nearly anoxic depositional conditions. Overall, the associated potential for oil and gas is high.

A second paleoenvironment is revealed by sample 8 at the top of the studied section, which consists of light gray marls and plots in field $\mathrm{V}$ of the Tyson ternary diagram (Fig. 6) and reflect an oxic platform (unconfined basin) conditions (Tyson 1993, 1995). The AOM of sample 8 is moderate $(30 \%)$ compared to that of the other samples and features a granulated texture. Palynomorphs $(55 \%)$ are abundant with a predominance of dinoflagellate cysts. This indicates that the initial paleoenvironment have been transitioned to evolve towards more oxic conditions. 


\section{Paleoenvironment reconstruction}

Quantitative and qualitative palynological analyses of the sediments yielded a rich and diverse association of dinoflagellate cysts ( 65 taxa) among the different strata and new datation have been assigned to this series: late Campanian-early Maastrichtian. This series records values from medium to high TOC values which leads us to propose that the depositional environment of this time could well be related to the ocean currents type Upwelling.

The binary diagram $\mathrm{Al}_{2} \mathrm{O}_{3}+\mathrm{K}_{2} \mathrm{O}+\mathrm{Na}_{2} \mathrm{O}$ vs $\mathrm{SiO} 2$ (Suttner and Dutta, 1986) (Fig. 7), makes possible to trace the climatic conditions prevailing at the time of deposits of the studied sediments. All the sediments treated show a fluctuation between arid and semi-humid periods.

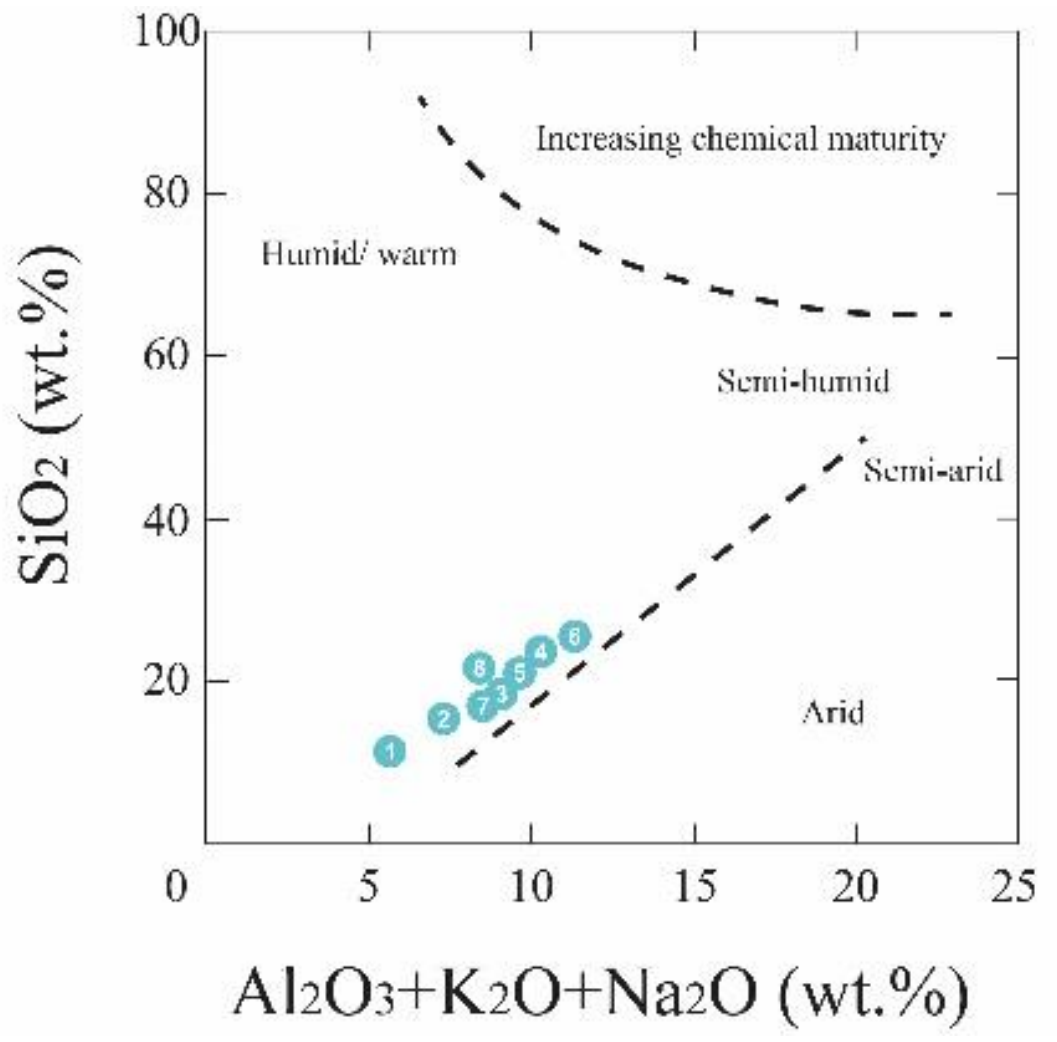

Fig 7: Discrimination diagrams $\mathrm{SiO}_{2}$ vs. $\left(\mathrm{Al}_{2} \mathrm{O}_{3}+\mathrm{K}_{2} \mathrm{O}+\mathrm{Na}_{2} \mathrm{O}\right)$ after Suttner and Dutta (1986)).

Regarding redox conditions, sediments formed in anoxic environments usually show enrichment of redox-sensitive trace metals such as $\mathrm{U}, \mathrm{Mo}, \mathrm{Cr}, \mathrm{Ni}, \mathrm{Cu}, \mathrm{As}, \mathrm{Zn}, \mathrm{Pb}, \mathrm{Cd}, \mathrm{Ag}$, and V (Rakociński et al. 2018). The signatures of sediments combined with mass balance calculations are commonly used to reconstruct changes in the past oceanic cycling of Mo and $\mathrm{U}$ and to estimate the extents of anoxia in the ancient ocean (Brüske et al. 2020). For this purpose, these two elements have been used or coupled with other proxies in several studies. In the present study, to get further insight about the redox conditions we used the $\mathrm{Th} / \mathrm{U}$ ratio (Figure 5) that can be more efficient than other trace metal (Racka et al. 2010; Rakociński et al. 2018). The $\mathrm{Th} / \mathrm{U}$ ratio of anoxic oil shales is less than 3 , while in carbonates this ratio is generally less than 1 (Myers \& Wignall 1987; Bond \& Zatoń, 2003; Bond et al. 2004). In the studied section, most samples yielded Th/U values less than 3 (Fig. 8), indicating anoxic conditions, but a few samples reflect typical oxic conditions. 
Molybdenum concentrations vary along the section without strong correlation. This may indicate decoupling redox behavior or possibly other sources for these elements in the sedimentary environment. Nevertheless, the overall concentration ranges could support anoxic conditions prevailed during sedimentation as it has been reported in other studies (Francois 1988; Wignall 1994; Brumsack 2006; Calvert \& Pedersen 2007; Motzer 2016). Still, bottom water conditions could have been rather dysoxic as indicated by $\mathrm{Th} / \mathrm{U}$ ratios. The studied sediments also formed in a low productivity regime, which is reflected by the high TOC values.

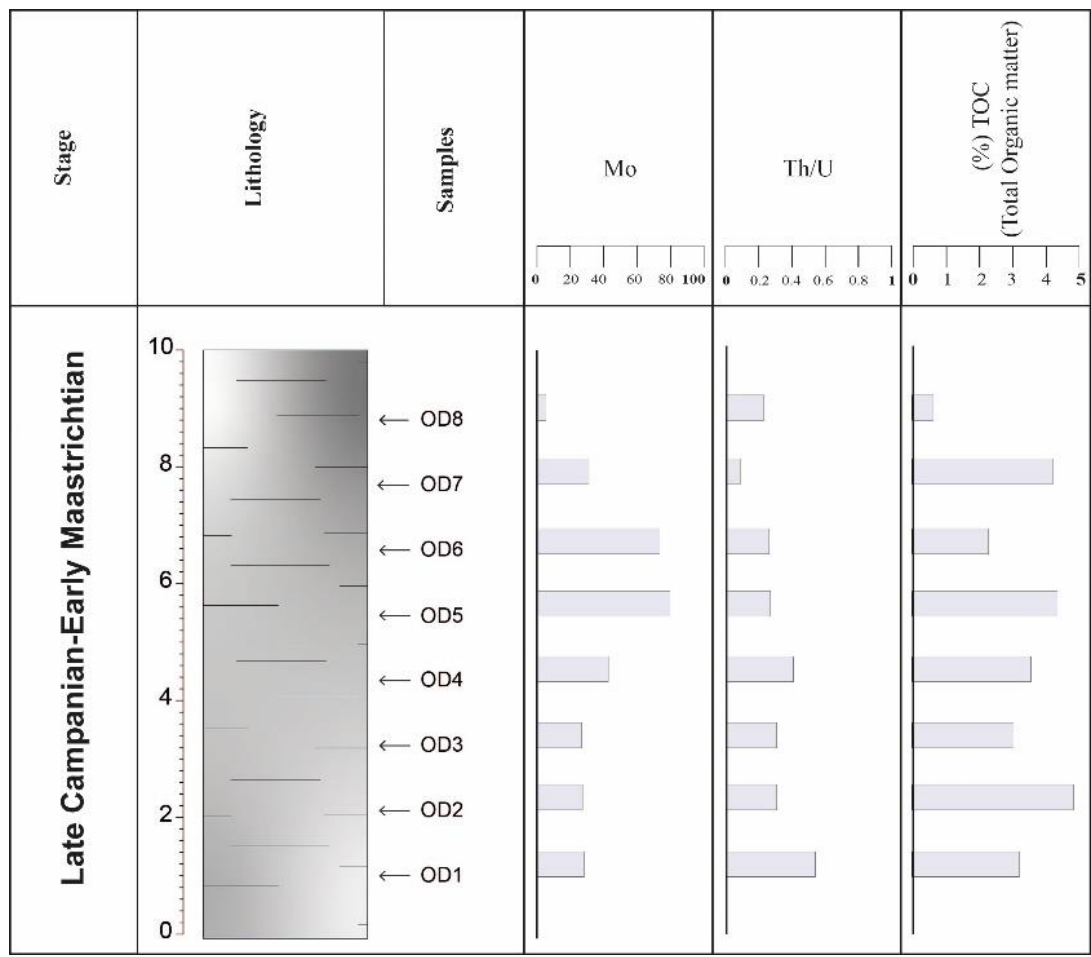

Fig 8: Composite plot of the section showing the thorium/uranium ratio, molybdenum contents and TOC contents in the studied section.

\section{Conclusion}

The present study was carried out to investigate biostratigraphy and organic geochemistry of an outcrop of the bituminous Sebkha Oum Debaa Formation in the Tarfaya-Laayoune coastal basin of Morocco. Quantitative and qualitative palynological analyses of the sediments yielded a rich and diverse association of dinoflagellate cysts (65 taxa) among the different strata. We propose a late Campanian age for this section due to the presence of internationally recognized index fossils and their stratigraphic importance: Andalusiella inflata, Andalusiella ivoirensis, Andalusiella mauthei, Cerodinium diebelii, Cerodinium speciosum, Dinogymnium acuminatum, Odontochitina porifera, Trichodinium castanea, and Trithyrodinium evittii. The results show associations of dinoflagellate cysts typical of the late Campanian, although those of the lower Maastrichtian cannot be definitively excluded.

Palynofacies and organic geochemistry revealed the presence of two paleoenvironment types. The first (from samples 1 to 7) represents reducing, confined conditions, with TOC levels ranging from $2.85-4.67 \mathrm{wt} . \%$, indicating a very high organic carbon content and good richness in the source rock (kerogen type II). Upwelling zones were highlighted by the dominance of peridinioids, which reflect intense paleoproductivity. These pulses of productivity are a major contributing factor for the accumulation of TOC during the Late Cretaceous, as have been demonstrated at previous locations (the Zin and Shfela basins and Tarfaya Basin). Through 
cysts (ecological markers), this paleoenvironment corresponds to two intervals tracing its evolution: the first (the base of the section), would be an outer neritic environment (by the high rate of Ondochitina group) and which would evolve towards an inner neritic environment (by the abundance of Andalusiella group).

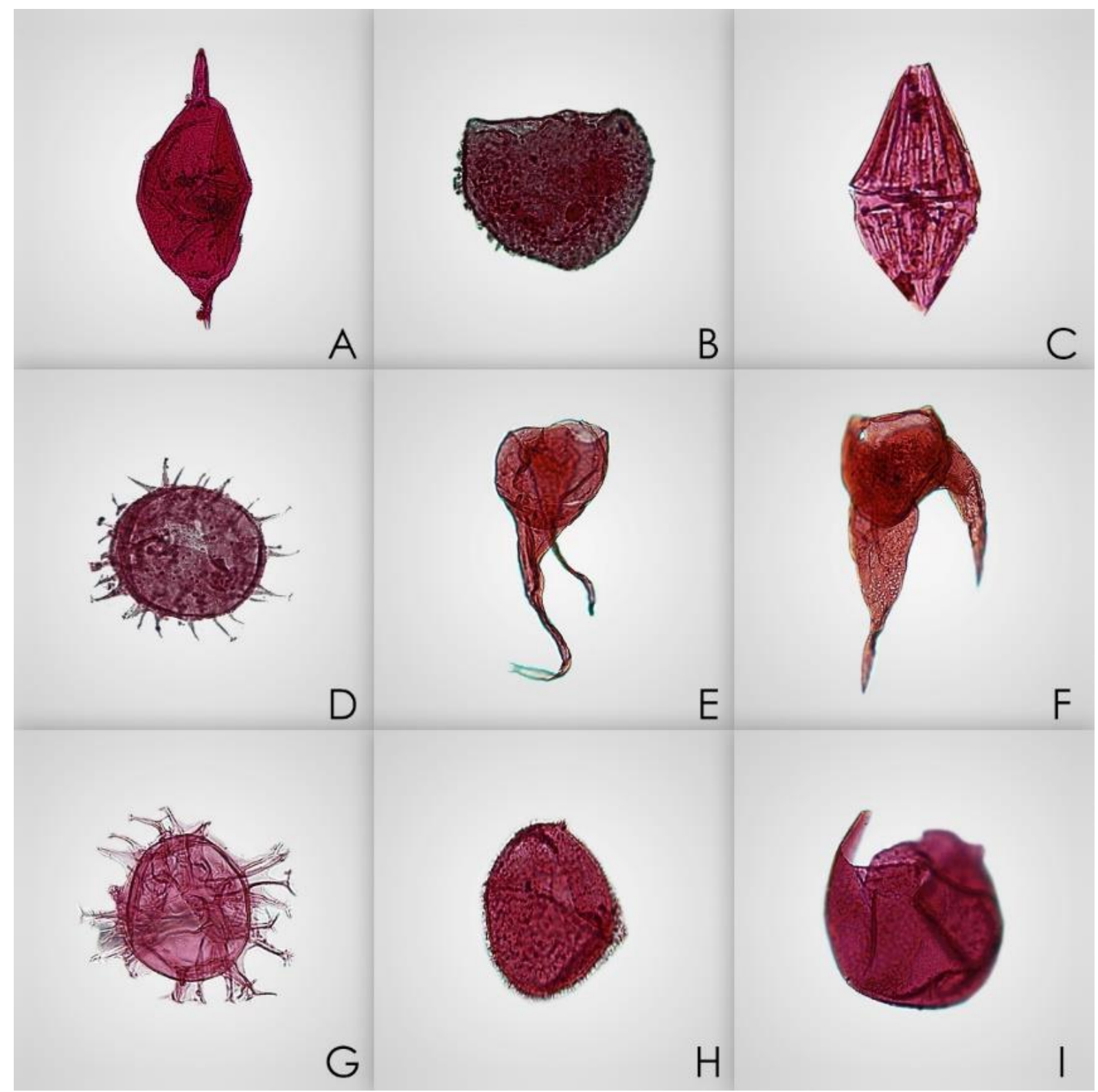

Plate 1: Dinoflagellate cysts in the Oum Debaa section, Tarfaya-Laayoune Basin, Morocco. Scale bar in all figures is $20 \mu \mathrm{m}$. A - Trichodinium castanea, sample OD 1, slide 1, EF W40; B - Acanthaulax wilsonii, sample OD 1, slide 1, EF Y10; C - Trichodinium castanea, sample OD 1, slide 2, EF T28/4; D - Dinogymnium elongatum, sample OD 8, slide 1, EF Y42/1; E - Xenascus ceratioides, sample OD 6, slide 2, EF X29/4; F - Trithyrodinium quinqueangulare, sample OD 8, slide 4, EF Z25/2; G - Dinogymnium sp.2, sample OD 2, slide 2, EF T10; H Dinogymnium acuminatum, sample OD 6, slide 1, EF E39/1; I - Dinogymnium denticulatum, sample OD 8 slide 1 , EF N29/1.

The second contrasting paleoenvironment (from sample 8), corresponding to the top of the section despite the series being monotonous, reflects oxic, unconfined conditions, with the lowest TOC $(0.51 \mathrm{wt} . \%)$ and the largest $\operatorname{Tmax}\left(608^{\circ} \mathrm{C}\right)$. The association of dominant cysts (the Dinogymnium and Exochosphaeridium groups) indicates a marginal environment which always remains under the influence of outer neritic environment. 
In conclusion, the present results challenge all previous interpretations of this region, particularly regarding the bituminous and phosphatic sedimentation continuing until the Maastrichtian. Earlier studies in this basin have largely attributed this age to thick phosphate sedimentation in deeper depressions in the SE region of the basin. This disparity highlights the necessity of updating our knowledge about the age of the phosphatic series and related geology of this area.

Data Availability: The datasets generated during and/or analysed during the current study are available from the corresponding author on reasonable request.

Acknowledgments: The authors would like to acknowledge the support through the R\&D Initiative - Appel à projets autour des phosphates APPHOS - sponsored by OCP (OCP Foundation, R\&D OCP, Mohammed VI Polytechnic University, National Center of Scientific and technical Research CNRST, Ministry of Higher Education, Scientific Research and Professional Formation of Morocco MESRSFC) under the project entitled *La série phosphatée Crétacé terminal-Paléogène du Gisement de Boucraa : Sédimentologie, Minéralogie, Géochimie, Stratigraphie Séquentielle et Implications Génétiques (Bassin d'Oued Eddahab, Maroc)*, project ID * GEOMOU01/2017*. We are very grateful to Dr. Ing Ech Cherki RJIMATI for guiding us in our first field reconnaissance missions. 


\section{Appendix $A$}

List of dinoflagellate cyst taxa observed in the Oum Debaa section. Dinocyst taxa are arranged in alphabetical order by genera and their nomenclature and references to their authors follow DINOFLAJ3 (Williams et al. 2017).

- Alisogymnium euclaense (Cookson and Eisenack, 1970a) Lentin and Vozzhennikova, 1990.

- Alterbidinium acutulum (Wilson, 1967b) Lentin and Williams, 1985.

- Alterbidinium minus (Alberti, 1959b) Lentin and Williams, 1985.

- Alterbidinium sp1.

- Alterbidinium spp.

- Alterbidinium varium Kirsch, 1991.

- Andalusiella dubia (Jain and Millepied, 1973) Lentin and Williams, 1980.

- Andalusiella inflata (Rauscher and Doubinger, 1982) Lentin and Williams, 1985.

- Andalusiella ivoirensis Masure et al. 1996.

- Andalusiella mauthei Riegel, 1974.

- Andalusiella polymorpha (Malloy, 1972) Lentin and Williams, $1977 b$.

- Andalusiella sp1.

- Andalusiella spp.

- Areoligera spp.

- Biconidinium reductum (May, 1980) Kirsch, 1991.

- Biconidinium spp.

- Bosedinia spp.

- Cannosphaeropsis utinensis Wetzel, 1933b.

- Cerodinium diebelii (Alberti, 1959b) Lentin and Williams, 1987.

- Cerodinium pannuceum (Stanley, 1965) Lentin and Williams, 1987.

- Cerodinium speciosum (Alberti, 1959b) Lentin and Williams, 1987.

- Chatangiella cf. robusta (Benson, 1976) Stover and Evitt, 1978.

- Circulodinium distinctum (Deflandre and Cookson, 1955) Jansonius, 1986.

- Cleistosphaeridium spp.

- Coronifera oceanica Cookson and Eisenack, 1958.

- Cribroperidinium wilsonii (Slimani, 1994) Schiøler et al. 1997.

- Cyclonephelium/Circulodinium.

- Cyclonephelium spp.

- Deflandrea spp.

- Diphyes colligerum (Deflandre and Cookson, 1955) Cookson, 1965.

- Dinogymnium acuminatum Evitt et al. 1967.

- Dinogymnium denticulatum (Alberti, 1961) Evitt et al. 1967.

- Dinogymnium digitus (Deflandre, 1936b) Evitt et al. 1967.

- Dinogymnium heterocostatum (Deflandre, 1936b) Evitt et al. 1967.

- Dinogymnium sp. Tahoun et al.2018.

- Dinogymnium spp.

- Dinogymnium westralium (Cookson and Eisenack, 1958) Evitt et al., 1967.

- Downiesphaeridium aciculare (Davey, 1969a) Islam, 1993.

- Exochosphaeridium bifidum (Clarke and Verdier, 1967) Clarke et al. 1968.

- Exochosphaeridium multifurcatum (Deflandre, 1937b) Masure in Fauconnier and Masure, 2004

- Exochosphaeridium sp1.

- Exochosphaeridium spp.

- Fibrocysta axialis (Eisenack, 1965b) Stover and Evitt, 1978. 
- Fibrocysta spp.

- Hafniasphaera fluens Hansen, 1977.

- Hafniasphaera septata (Cookson and Eisenack, 1967) Hansen, 1977.

- Odontochitina porifera Cookson, 1956.

- Odontochitina operculata (Wetzel, 1933a) Deflandre and Cookson, 1955.

- Oligosphaeridium spp.

- Pervosphaeridium spp.

- Pervosphaeridium tubuloaculeatum Slimani, 1994.

- Senoniasphaera inornata (Drugg, 1970b) Stover and Evitt, 1978.

- Spiniferites bejui Masure et al. 1998.

- Spiniferites membranaceus (Rossignol, 1964) Sarjeant, 1970.

- Spiniferites monilis (Davey and Williams, 1966a) Sarjeant, 1970.

- Spiniferites nodosus (Wall, 1967) Sarjeant, 1970.

- Spiniferites ramosus (Ehrenberg, 1837b, pl.1, fig.15) Mantell, 1854.

- Spiniferites/Achomosphaera.

- Spiniferites spp.

- Tanyosphaeridium regulare Davey and Williams, $1966 \mathrm{~b}$.

- Tanyosphaeridium variecalamum Davey and Williams, $1966 \mathrm{~b}$.

- Tanyosphaeridium xanthiopyxides (Wetzel, 1933b) Stover and Evitt, 1978.

- Thalassiphora pelagica (Eisenack, 1954b) Eisenack and Gocht, 1960.

- Trichodinium castanea (Deflandre, 1935) Clarke and Verdier, 1967.

- Trithyrodinium evittii Drugg, 1967.

- Trithyrodinium quinqueangulare Marheinecke, 1992.

- Trithyrodinium suspectum (Manum and Cookson, 1964) Davey, 1969b.

- Trithyrodinium spp.

- Xenascus ceratioides (Deflandre, 1937b) Lentin and Williams, 1973.

- Xenascus perforatus (Vozzhennikova, 1967) Yun Hyesu, 1981. 


\section{References}

Abioui M., Ferry S., Grosheny D., Içame N., Robert E. \& Benssaou M. (2019): The Cretaceous marine onlap on Palaeozoic deposits (Smara-Lâayoune Basin, South Morocco). Comparison with neighbouring regions. Comptes Rendus. - Geoscience 351(7): 498-507.

Albani A., Kuhnt W., Luderer F., Herbin J.P. \& Caron M. (1999): Palaeoenvironmental evolution of the Late Cretaceous sequence in the Tarfaya Basin (southwest of Morocco). - Geological Society Special Publication 153(1): 223-240.

Ali S., Stattegger K., Liu Z., Khélifi N. \& Kuhnt W. (2019): Paleoclimatic and paleoenvironmental reconstruction at Tarfaya Atlantic coastal basin (Morocco) based on clay mineral records from Upper Cretaceous to Quaternary. - Arabian Journal of Geosciences 12(1): 1-12.

Almogi-Labin A., Bein A. \& Sass E. (1993): Late Cretaceous upwelling system along the Southern Tethys Margin (Israel): Interrelationship between productivity, bottom water environments, and organic matter preservation. - Paleoceanography 8(5): 671-690.

Antonescu E., Foucher J.C. \& Odin G.S. (2001): Chapitre C2c Les kystes de dinoflagellés de la carrière de tercis les bains (Landes, France). - Developments in Palaeontology and Stratigraphy 19(C): 235-252.

Antonescu E., Foucher J.C., Odin G.S., Schiøler P., Sieg1-Farkas A. \& Wilson G.J. (2001): Chapter C2d Dinoflagellate cysts in the Campanian-Maastrichtian succession of Tercis les Bains (Landes, France), a synthesis. - Developments in Palaeontology and Stratigraphy 19(C): 253-264.

Aquit M., Kuhnt W., Holbourn A., Chellai E., Stattegger K., Kluth O. \& Jabour H. (2013): Late cretaceous paleoenvironmental evolution of the tarfaya atlantic coastal basin, SW morocco. - Cretaceous Research 45: 288-305.

Aquit M., Kuhnt W., Holbourn A., Chellai E.H., Lees J.A., Kluth O. \& Jabour H. (2017): Complete archive of late Turonian to early Campanian sedimentary deposition in newly drilled cores from the Tarfaya Basin, SW Morocco. - Bulletin of the Geological Society of America 129(1-2): 137-151.

Arthur M.A. \& Natland J.H. (2011): Carbonaceous sediments in the North and South Atlantic: The role of salinity in stable stratification of early Cretaceous basins (pp. 375-401), American Geophysical Union (AGU).

Aurisano R.W. (1989): Upper cretaceous dinoflagellate biostratigraphy of the subsurface Atlantic coastal plain of New Jersey and Delaware, U.S.A. - Palynology 13(1): 143-179.

El Ayyat A.M. (2015): Lithostratigraphy, sedimentology, and cyclicity of the Duwi Formation (late Cretaceous) at Abu Tartur plateau, Western Desert of Egypt: evidences for reworking and redeposition. Arabian Journal of Geosciences 8(1): 99-124.

Begouën V., Masure E., Bellier J.P. \& Debroas E.J. (1990): Premier inventaire des kystes de dinoflagellés des flyschs néocrétacés de la zone sous-pyrénéenne (France): biostratigraphie comparée et. - Comptes rendus de l'Académie des sciences 311(11): 1383-1389.

El Beialy S.Y. (1995): Campanian-Maastrichtian palynomorphs from the Duwi (Phosphate) Formation of the Hamrawein and Umm El Hueitat mines, Red Sea Coast, Egypt. - Review of Palaeobotany and Palynology 85(3-4): 303-317.

E1 Beialy S.Y., El Atfy H.S., Zavada M.S., El Khoriby E.M. \& Abu-Zied R.H. (2010): Palynological, alynofacies, paleoenvironmental and organic geochemical studies on the Upper Cretaceous succession of the GPTSW-7 well, North Western Desert, Egypt. - Marine and Petroleum Geology 27(2): 370-385.

Beil S., Kuhnt W., Holbourn A.E., Aquit M., Flögel S., Chellai E.H. \& Jabour H. (2018): New insights into Cenomanian paleoceanography and climate evolution from the Tarfaya Basin, southern Morocco. - Cretaceous Research 84: 451-473.

Beilstein U. (1994): Mikrofloren (Sporomorphen, Dinophyceen) aus der regressiven Oberkreide des BenueTroges, Nigeria. Geologisches Institut der Universität zu Köln.

Benalioulhaj N. (1991): Les formations a phosphates et a schistes bitumineux du bassin des oulad-abdoun et du bassin de timahdit; petrographie, mineralogie, geochimie et environnement de depot. Université Louis Pasteur (Strasbourg).

Benalioulhaj S. \& Trichet J. (1990): Comparative study by infrared spectroscopy of the organic matter of phosphate-rich (Oulad Abdoun basin) and black shale (Timahdit basin) series (Morocco). - Organic Geochemistry 16(4-6): 649-660.

Benammi M., Adnet S., Marivaux L., Yans J., Noiret C., Tabuce R. \& Surault J. (2019): Geology, biostratigraphy and carbon isotope chemostratigraphy of the Palaeogene fossil-bearing Dakhla sections, southwestern Moroccan Sahara. Geological Magazine. Cambridge University Press.

Blakey R.C. (2008): Gondwana paleogeography from assembly to breakup - A 500 m.y. odyssey. - Special Paper of the Geological Society of America 441: 1-28. 
Boltenhagen E. (1977): Microplancton du Crétacé supérieur du Gabon. (Éditions du Centre national de la recherche scientifique, Ed.). Cah. Paléontol.

Brebion P. \& Ortlieb L. (1976): Nouvelles recherches géologiques et malacologiques sur le Quaternaire de la province de Tarfaya (Maroc méridional). - Geobios 9(5): 529-549.

Brinkhuis H. (1994): Late Eocene to Early Oligocene dinoflagellate cysts from the Priabonian type-area (Northeast Italy): biostratigraphy and paleoenvironmental interpretation. - Palaeogeography, Palaeoclimatology, Palaeoecology 107(1-2): 121-163.

Brinkhuis H., Bujak J.P., Smit J., Versteegh G.J.M. \& Visscher H. (1998): Dinoflagellate-based sea surface temperature reconstructions across the Cretaceous-Tertiary boundary. - Palaeogeography, Palaeoclimatology, Palaeoecology 141(1-2): 67-83.

Brinkhuis H., Sengers S., Sluijs A., Warnaar J. \& Williams G. (2003): Latest Cretaceous to earliest Oligocene, and Quaternary dinoflagellate cysts from ODP Site 1172, East Tasman Plateau. - Proceedings of the ocean drilling program (pp. 1-48), Scientific results.

Bujak J.P. (1984): Cenozoic dinoflagellate cysts and acritarchs from the Bering Sea and northern North Pacific, DSDP Leg 19. - Micropaleontology 30(2): 180-212.

Bujak J.P. \& Williams G.L. (1985): Mesozoic and Cenozoic dinoflagellates. Plankton Stratigraphy (pp. 847-965).

Calvert S.E. \& Pedersen T.F. (2007): Chapter Fourteen Elemental Proxies for Palaeoclimatic and Palaeoceanographic Variability in Marine Sediments: Interpretation and Application: Developments in Marine Geology, v. 1, pp. 567-644.

Choubert G. (1946): Géologie-Sur L'age Des Regs Quaternaires du Sud marocain et de l'apparition de Labbevillien au Maroc. Comptes Rendus Hebdomadaires Des Sciences De L'Academie Des Sciences 223(22): 911-912.

Choubert G., Faure-Muret A. \& Hottinger L. (1966): Apercu geologique du bassin cotier de Tarfaya. (Service Géologique du Maroc, Ed.).

Einsele G. \& Von Rad U. (1979): Facies and paleoenvironment of Lower Cretaceous sediments at DSDP Site 397 and in the Aaiun Basin (Northwest Africa). - Initial Rep. of the Deep Sea Drilling Project 47(1): $559-77$.

Einsele G. \& Wiedmann J. (1982): Turonian black shales in the Moroccan coastal basins: first upwelling in the Atlantic Ocean? Geology of the northwest African continental margin, pp. 396-414.

El-Shafeiy M., Birgel D., El-Kammar A., El-Barkooky A., Wagreich M., Mohamed O. \& Peckmann J. (2014): Palaeoecological and post-depositional changes recorded in CampanianMaastrichtian black shales, Abu Tartur plateau, Egypt. - Cretaceous Research 50: 38-51.

El-Shafeiy M., Birgel D., El-Kammar A., El-Barkooky A., Wagreich M., Tahoun S. \& Peckmann, J. (2017): Integrated palaeo-environmental proxies of the Campanian to Danian organicrich Quseir section, Egypt. - Marine and Petroleum Geology 86: 771-786.

Ela N.M.A., Tahoun S.S. \& Raafat A. (2019): The Cretaceous (Barremian-Maastrichtian) palynostratigraphy and palynofacies of the Drazia-1 well, North Egypt.

Eshet Y., Almogi-Labin A. \& Bein A. (1994): Dinoflagellate cysts, paleoproductivity and upwelling systems: A Late Cretaceous example from Israel. - Marine Micropaleontology 23(3): 231-240.

Fabre S., Lézin C. \& Lebedel V. (2018): Paleoceanographic significance of cerium anomalies during the oae 2 on the NW African margin. - Journal of Sedimentary Research 88(11): 1284-1299.

Fensome R.A. \& Williams G.L. (2004): The Lentin and Williams index of fossil dinoflagellates.

Firth J.V. (1987): Dinoflagellate biostratigraphy of the maastrichtian to danian interval in the U.S. Geological survey Albany core, Georgia, U.S.A. - Palynology 11(1): 199-216.

Föllmi K.B. (2012): Early Cretaceous life, climate and anoxia: Cretaceous Research, v. 35, pp. 230-257.

François R. (1988): A study on the regulation of the concentrations of some trace metals (Rb, $\mathrm{Sr}, \mathrm{Zn}, \mathrm{Pb}$, $\mathrm{Cu}, \mathrm{V}, \mathrm{Cr}, \mathrm{Ni}, \mathrm{Mn}$ and Mo) in Saanich Inlet Sediments, British Columbia, Canada: Marine Geology, v. 83, pp. 285-308.

Garzon S. Warny S. \& Bart P.J. (2012): A palynological and sequence-stratigraphic study of SantonianMaastrichtian strata from the Upper Magdalena Valley basin in central Colombia. - Palynology 36(suppl. 1): 112-133.

Ghassal B.I., Littke R., Sachse V., Sindern S. \& Schwarzbauer J. (2016): Depositional environment and source rock potential of Cenomanian and Turonian sedimentary rocks of the Tarfaya Basin, Southwest Morocco. - Geologica Acta 14(4): 419-441.

Goudie A. (2013): Arid and Semi-Arid Geomorphology. Cambridge University Press. 
Habib D., Olsson R.K., Liu C. \& Moshkovitz S. (1996): High-resolution biostratigraphy of sea-level low, biotic extinction, and chaotic sedimentation at the Cretaceous-Tertiary boundary in Alabama, north of the Chicxulub. - Geological Society of America Special Paper 307: 243-252.

Hartwig A., di Primio R., Anka Z. \& Horsfield B. (2012): Source rock characteristics and compositional kinetic models of Cretaceous organic rich black shales offshore southwestern Africa. - Organic Geochemistry 51: 17-34.

Harwood R.J. (1977): Oil and Gas Generation by Laboratory Pyrolysis of Kerogen. AAPG Bulletin 61(12): 20822102.

Le Heron D.P., Khoukhi Y., Paris F., Ghienne J.F. \& Le Herissé A. (2008): Black shale, grey shale, fossils and glaciers: Anatomy of the Upper Ordovician-Silurian succession in the Tazzeka Massif of eastern Morocco. - Gondwana Research 14(3): 483-496.

Ionnides N.S. (1986): Dinoflagellate cysts from Upper Cretaceous-Lower Tertiary sections, Bylot and Devon Islands. Arctic Archipelago. - Bull. Geol. Surv. Can 371: 1-99.

Keller G., Adatte T., Berner Z., Chellai E.H. \& Stueben D. (2008): Oceanic events and biotic effects of the Cenomanian-Turonian anoxic event, Tarfaya Basin, Morocco. - Cretaceous Research 29(5-6): 976994.

Kirsch K. (1991): Dinoflagellatenzysten aus der Oberkreide des Helvetikums und Nordultrahelvetikums von Oberbayern. - Geowissenschaftliche Abhandlungen, Reihe A. Geol. Paläontol 22: 1-306.

Kjellström G. (1973): Maastrichtian microplankton from the Höllviken Borehole No.1 in Scania, southern Sweden. Sveriges Geologiska Undersökning, Serie C, 67(8): 1-59.

Kolonic S., Sinninghe J.S., Bottcher M.E., Kuypers M.M.M., Kuhnt W., Beckmann B., Scheeder G., et al. (2002): Geochemical Characterization Of Cenomanian/Turonian Black Shales From The Tarfaya Basin (Sw Morocco). Relationships Between Palaeoenvironmental Conditions And Early Sulphurization Of Sedimentary Organic Matter. - Journal of Petroleum Geology 25(3): 325-350.

Kuhnt W., Chellai E.H., Holbourn A., Luderer F., Thurow J., Wagner T., Albani A.E., et al. (2001): Morocco Basin's sedimentary record may provide correlations for Cretaceous paleoceanographic events worldwide. - Eos, Transactions American Geophysical Union 82(33): 361-361.

Kuhnt W., Luderer F., Nederbragt S., Thurow J. \& Wagner T. (2005): Orbital-scale record of the late Cenomanian-Turonian oceanic anoxic event (OAE-2) in the Tarfaya Basin (Morocco). - International Journal of Earth Sciences 94(1): 147-159.

Kuhnt W. \& Moullade M. (1991): Quantitative analysis of Upper cretaceous abyssal agglutinated foraminiferal distribution in the North Atlantic: Paleoceanographic implications. - Revue de Micropaléontologie 34(4): 313-349.

Kurita H. \& McIntyre D.J. (1995): Paleocene dinoflagellates from the turtle mountain formation, southwestern Manitoba, Canada. - Palynology 19(1): 119-136.

Landman N.H., Johnson R.O. \& Edwards L.E. (2004): Cephalopods from the Cretaceous/Tertiary boundary interval on the Atlantic Coastal Plain, with a description of the highest ammonite zones in North America. Part 2. - Bulletin of the American Museum of Natural History 287: 1-107.

Lebedel V., Lézin C., Andreu B., Ettachfini E.M., \& Grosheny D. (2015) : The upper Cenomanianlower Turonian of the Preafrican Trough (Morocco): Platform configuration and palaeoenvironmental conditions. - Journal of African Earth Sciences 106: 1-16.

Lebedel V., Lezin C., Andreu B., Wallez M.J., Ettachfini E.M. \& Riquier L. (2013): Geochemical and palaeoecological record of the Cenomanian-Turonian Anoxic Event in the carbonate platform of the Preafrican Trough, Morocco. - Palaeogeography, Palaeoclimatology, Palaeoecology 369: 79-98.

Lecointre G. (1949): Sur le Quaternaire des environs de Casablanca. - Bulletin de la Société Géologique de France 5(7-9): 585-594.

Lentin J.K. (1993): Fossil dinoflagellates: index to genera and species 1993 edition. - Amer. Assoc. Stratigraphic Palynologists, Contribution Series 28. Retrieved May 2, 2020 (https://ci.nii.ac.jp/ naid/10009322336)

Lentin J.K. \& Williams G.L. (1985): Fossil dinoflagellates: index to genera and species, 1985 edition. Canadian Technical Report of Hydrography and Ocean Sciences, no.60.

Lewis J., Dodge J. \& Powell A. (1990): 18. Quaternary dinoflagellate cysts from the upwelling system offshore Peru, Hole 686b, odp leg 1121. - Proceedings of the Ocean Drilling Program, scientific results (Vol. 112, pp. 323-328).

Lindner A. \& Querol R. (1971): Mapa geologico del Sahara español 1: 200 000. (M. Instituto Geologico y Minero de España, Ed.). 
Littler K., Robinson S.A., Bown P.R., Nederbragt A.J., and Pancost R.D. (2011): High sea-surface temperatures during the Early Cretaceous Epoch: Nature Geoscience, v. 4, pp. 169-172.

Lüning S., Kolonic S., Belhadj E.M., Belhadj Z., Cota L., Barić G. \& Wagner T. (2004): Integrated depositional model for the Cenomanian-Turonian organic-rich strata in North Africa. - Earth-Science Reviews 64(1-2): 51-117.

Marheinecke U. (1992): Monographie der dinocysten, acritarcha und chlorophyta des Maastrichtium von Hemmoor (Niedersachsen). - Palaeontographica Abteilung B 227: 1-173.

Masure E. (1985): Kystes de dinoflagellés. Le Campanien stratotypique: étude lithologique et micropaléontologique. - Géologie Méditerranéenne 10(3-4): 41-57.

Masure E., Rauscher R., Dejax J., Schuler M. \& Ferre B. (1998): Cretaceous-Paleocene palynology from the Côte d'Ivoire-Ghana transform margin, sites 959-962. - Proceedings of the Ocean Drilling Program (pp. 253-276).

Masure E. \& Tea J. (1996): The dinoflagellate Andalusiella: emendation of the genus, revision of species, A. ivoirensis Masure, Tea and Yao, sp. nov. - Review of Palaeobotany and Palynology 91(1-4): 171-186.

May F. (1980): Dinoflagellate cysts of the Gymnodiniaceae, Peridiniaceae, and Gonyaulacaceae from the Upper Cretaceous Monmouth Group, Atlantic Highlands. - Palaeontogr. B: 10-116.

McIntyre D.J. (1999): Campanian to Paleocene dinoflagellate assemblages from the Turtle Mountain core hole, Manitoba, western Canada. - Canadian Journal of Earth Sciences 36(5): 769-774.

Meinhold G., Howard J.P., Strogen D., Kaye M.D., Abutarruma Y., Elgadry M., Thusu B., et al. (2013): Hydrocarbon source rock potential and elemental composition of lower Silurian subsurface shales of the eastern Murzuq Basin, southern Libya. - Marine and Petroleum Geology 48: 224-246.

Meister C., Piuz A., Cavin L., Boudad L., Bacchia F., Ettachfini E.M. \& Benyoucef M. (2017): Late Cretaceous (Cenomanian-Turonian) ammonites from southern Morocco and south western Algeria. - Arabian Journal of Geosciences 10(1): 1-46.

Motzer W.E., (2016): Chemistry, geochemistry, and geology of chromium and chromium compounds, in Chromium (VI) Handbook: CRC Press, pp. 23-91.

Myers K.J., \& Wignall P.B., (1987): Understanding Jurassic Organic-rich Mudrocks-New Concepts using Gamma-ray Spectrometry and Palaeoecology: Examples from the Kimmeridge Clay of Dorset and the Jet Rock of Yorkshire, in Marine Clastic Sedimentology: Springer Netherlands, pp. 172-189. https://link.springer.com/chapter/10.1007/978-94-009-3241-8_9. Checked September 2020.

Nøhr-Hansen H. (1996): Upper Cretaceous dinoflagellate cyst stratigraphy, onshore West Greenland. Grønlands Geologiske Undersøgelse Bulletin 170: 104.

- (2012): Palynostratigraphy of the Cretaceous-lower Palaeogene sedimentary succession in the Kangerlussuaq Basin, southern East Greenland. - Review of Palaeobotany and Palynology 178: 59-90.

Nguidi M.A., Mouflih M., Benbouziane A., Kocsis L., El Ouariti S., E1 Boukhari H., Aquit M., \& Yazami O.K. (2021): Lithofacies analysis, sedimentary dynamics and genesis of MaastrichtianEocene phosphorites of BouCraa deposit (Southern Morocco): Journal of African Earth Sciences, v. 177, pp. 104-161.

Nzoussi-Mbassani P., Khamli N., Disnar J.R., Laggoun-Défarge F. \& Boussafir M. (2005): Cenomanian-Turonian organic sedimentation in North-West Africa: A comparison between the Tarfaya (Morocco) and Senegal Basins. - Sedimentary Geology 177(3-4): 271-295.

Oboh-Ikuenobe F.E., Yepes O. \& Gregg J.M. (1998): Palynostratigraphy, Palynofacies, and thermal maturation of Cretaceous - Paleocene sediments from The Côte D'ivoire-Ghana Transform Margin. In: Mascle M., Lohmann J. \& Moullade G.P. [Ed.] Proceedings of the Ocean Drilling Program.

Pellicer R. (2016): Improvement of biostratigraphic and paleoenvironmental reconstruction tools based on cretaceous dinoflagellate cysts from the tethys and the atlantic: Paris VI, 262 p. https://tel.archivesouvertes.fr/tel-01691423. Checked May 2020.

Pirrie D., Crame J.A., Lomas S.A. \& Riding J.B. (1997): Late Cretaceous stratigraphy of the Admiralty Sound region, James Ross Basin, Antarctica. - Cretaceous Research 18(1): 109-137.

Pletsch T., Erbacher J., Holbourn A.E.L., Kuhnt W., Moullade M., Oboh-Ikuenobede F.E., Söding E., et al. (2001): Cretaceous separation of Africa and South America: The view from the West African margin (ODP Leg 159). - Journal of South American Earth Sciences 14(2): 147-174.

Powell A.J., Dodge J.D. \& Lewis J. (1990): 17. Late Neogene To Pleistocene Palynological Facies Of The Peruvian Continental Margin Upwelling, Leg 1121. - Proceedings of the Ocean Drilling Project, Scientific Results, 112: 297-321. 
Prauss M.L. (2015): Marine palynology of the Oceanic Anoxic Event 3 (OAE3, Coniacian - Santonian) at Tarfaya, Morocco, NW Africa - transition from preservation to production controlled accumulation of marine organic carbon. - Cretaceous Research 53: 19-37.

Premaor E., de Souza P.A., Arai M. \& Helenes J. (2010): Palinomorfos do Campaniano (Cretáceo Superior) da Bacia de Pelotas, Rio Grande do Sul: Implicações bioestratigráficas e paleoambientais. Pesquisas em Geociencias 37(1): 63-79.

Price L.C., Pawlewicz M.J. \& Daws T.A. (1999): Organic metamorphism in the California petroleum basins; Chapter A, Rock-Eval and vitrinite reflectance: https://pubs.er.usgs.gov/publication/b2174A. Checked May 2020.

Rachidi M., Neuweiler F. \& Kirkwood D. (2009): Diagenetic-Geochemical Patterns and Fluid Evolution History Of A Lower Jurassic Petroleum Source Rock, Middle Atlas, Morocco. - Journal of Petroleum Geology 32(2): 111-128.

Racka M., Marynowski L., Filipiak P., Sobstel M., Pisarzowska A., \& Bond D.P.G. (2010): Anoxic Annulata Events in the Late Famennian of the Holy Cross Mountains (Southern Poland): Geochemical and palaeontological record: Palaeogeography, Palaeoclimatology, Palaeoecology, v. 297, pp. 549-575.

Radmacher W., Tyszka J., Mangerud G. \& Pearce M.A. (2014): Dinoflagellate cyst biostratigraphy of the Upper Albian to Lower Maastrichtian in the southwestern Barents Sea. Marine and Petroleum Geology 57: 109-121.

Rakociński M., Zatoń M., Marynowski L., Gedl P., \& Lehmann J. (2018): Redox conditions, productivity, and volcanic input during deposition of uppermost Jurassic and Lower Cretaceous organicrich siltstones in Spitsbergen, Norway: Cretaceous Research, v. 89, pp. 126-147.

Ratschiller L.K. (1970): Lithostratigraphy of the northern Spanish Sahara. Museo tridentino di scienze naturali.

Rauscher R. \& Doubinger J. (1981): Palynostratigraphic Results In The Phosphatic Maestrichtian Of Morocco. - Comptes Rendus De L'Academie Des Sciences 293(4): 321-324.

Razmjooei M.J., Thibault N., Kani A., Dinarès-Turell J., Pucéat E., Shahriari S. \& Radmacher W. (2018): Integrated bio- and carbon-isotope stratigraphy of the Upper Cretaceous Gurpi Formation (Iran): A new reference for the eastern Tethys and its implications for large-scale correlation of stage boundaries. - Cretaceous Research 91: 312-340.

Riding J.B., Keating J.M., Snape M.G., Newham S. \& Pirrie D. (1992): Preliminary Jurassic and Cretaceousdinoflagellate cyst stratigraphy of the James Ross Island area, Antarctic Peninsula. Newsletters on Stratigraphy, pp. 19-39.

Riegel W. \& Sarjeant W.A.S. (1982): Dinoflagellate cysts from the Upper Cretaceous of southern Spain: new morphological and taxonomic observations - Résultats de votre recherche - Bases bibliographiques Pascal et Francis. - Neues Jahrbuch für Geologie und Paläontologie, Abhandlungen 162(3): 286-303.

Rjimati E., Id Sahara M., Amzahrou M., Essalmani B., Mustaphi H., Zemmouri A. \& Benlkhedim A. (2002): Carte Géologique Sebkhat Oum Deba’, 1:100 000. (N. et mémoires n494 Edition du service géologique du Maroc).

Rjimati E., Michard A. \& Saddiqi O. (2011): Anti-Atlas occidetal et provinces sahariennes. - Notes mémoires du Serv. Géologique n561: pp. 1-95.

Rjimati E. \& Zemmouri A. (2009): Carte géologique du Maroc au 1/100 000-Feuille de Laâyoune-NG 28XXIII-2- Notice explicative. Notes et mémoires du Service Géologique n492 bis.

Robinson V.D. \& Engel M.H. (1993): Characterization of the Source Horizons Within the Late Cretaceous Transgressive Sequence of Egypt: Chapter 7, 33: 101-117.

Roncaglia L. \& Corradini D. (1997): Correlation of key dinoflagellate events with calcareous nannoplankton and planktonic foraminiferal zones in the Solignano Formation (Maastrichtian, Late. Review of Palaeobotany and Palynology 97(1-2): 177-196.

Sachse V.F., Heim S., Jabour H., Kluth O., Schümann T., Aquit M. \& Littke R. (2014): Organic geochemical characterization of Santonian to Early Campanian organic matter-rich marls (Sondage No. 1 cores) as related to OAE3 from the Tarfaya Basin, Morocco. Marine and Petroleum Geology. Elsevier Ltd.

Sachse V.F., Littke R., Heim S., Kluth O., Schober J., Boutib L. \& Jabour H. (2011) Petroleum source rocks of the Tarfaya Basin and adjacent areas, Morocco. - Organic Geochemistry 42(3): 209-227.

Schrank E. (1987): Palaeozoic and Mesozoic palynomorphs from northeast Africa (Egypt and Sudan) with special reference to Late Cretaceous pollen. - Berl. Geowiss. Abh. A 75: 249-310.

Schrank E. \& Mia I. (1995): Cretaceous (Aptian-Maastrichtian) palynology of foraminifera-dated wells (KRM1, AG-18) in northwestern Egypt. - Mitt Mus Natkd Berl, Geowiss Reihe 1: 144-167. 
Slimani H. (1995): Les Dinokystes des craies du Campanien au Danien à Hallembaye et Turnhout (Belgique), et à Beutenaken (Pays-Bas): Biostratigraphie et systematique. Research Unit Palaeontology, Ghent University.

- (2001a): New species of dinoflagellate cysts from the Campanian-Danian chalks at Hallembaye and Turnhout (Belgium) and at Beutenaken (the Netherlands). - Journal of Micropalaeontology (Vol. 20).

- (2001b): Les kystes de dinoflagellés du Campanien au Danien dans la région de Maastricht (Belgique et PaysBas) et de Turnhout (Belgique): biozonation et corrélation avec d'autres régions en Europe occidentale. - Geol. Palaeontol 35: 161-201.

Slimani H., Louwye S., Dusar M. \& Lagrou D. (2011): Connecting the Chalk Group of the Campine Basin to the dinoflagellate cyst biostratigraphy of the Campanian to Danian in borehole Meer (northern Belgium). Geologie en Mijnbouw. - Netherlands Journal of Geosciences 90(2-3): 129-164.

Sluijs A., Pross J. \& Brinkhuis H. (2005): From greenhouse to icehouse: organic-walled dinoflagellate cysts as paleoenvironmental indicators in the Paleogene. - Earth-Science Reviews 68(3-4): 281-315.

Smith S.A., Levy M.G. \& Noga E.J. (1992): Development of an enzyme-linked immunosorbent assay (ELISA) for the detection of antibody to the parasitic dinoflagellate Amyloodinium ocellatum in Oreochromis. - Veterinary parasitology 42: 145-155.

Soncini M.J. \& Rauscher R. (1988): Association de dinokystes du Maastrichtien superieur phosphate au Maroc. Bulletin des Centres de recherches exploration-production Elf-Aquitaine 12(1): 427-450.

Stover L., Brinkhuis H., Damassa S.P., de Verteuil L., Helby R.J., Monteil E., Partridge A.D., et al. (1996): Mesozoic-Tertiary dinoflagellates, acritarchs and prasinophytes. Palynology: principles and applications 2 .

Suttner L.J. \& Dutta P.K., (1986): Alluvial sandstone composition and paleoclimate, I. Framework mineralogy.: Journal of Sedimentary Petrology, v. 56, pp. 329-345.

Tahoun S.S., Deaf A.S. \& Ied I.M. (2018): The use of cyclic stratigraphic pattern of peridinioid and gonyaulacoid dinoflagellate cysts in differentiating potential thick monotonous carbonate reservoirs: A possible. - Marine and Petroleum Geology 96: 240-253.

Tahoun S.S. \& Ied I.M. (2019): A Cretaceous dinoflagellate cyst palynozonation of northern Egypt. Palynology 43(3): 394-410.

Tea-Yassi J., Digbehi Z.B., Yao K.R. \& Glohi B.V. (1999): Etude de quelques palynomorphes du cretace superieur du bassin offshore de cote d'Ivoire: Implications biostratigraphiques et paleoenvironmentales. - Journal of African Earth Sciences 29(4): 783-798.

Tissot B.P. \& Welte D.H. (1984): Petroleum formation and occurrence. Springer Science \& Business Media. Tourtelot H.A. (1979): Black shale - its deposition and diagenesis. - Clay and Clay Minerals 27(5): 313-321.

Tyson R.V. (1993): Palynofacies Analysis. - Applied Micropalaeontology (pp. 153-191).

- (1995). Abundance of Organic Matter in Sediments: TOC, Hydrodynamic Equivalence, Dilution and Flux Effects. - Sedimentary Organic Matter (pp. 81-118).

Von Rad U. \& Wissmann G. (1982): Cretaceous-Cenozoic History of the West Saharan Continental Margin (NW Africa): Development, Destruction and Gravitational Sedimentation, pp. 106-131. Springer, Berlin, Heidelberg.

Wall D., Dale B., Lohmann G. P. \& Smith W.K. (1977): The environmental and climatic distribution of dinoflagellate cysts in modern marine sediments from regions in the North and South Atlantic Oceans and adjacent seas. - Marine Micropaleontology 2(C): 121-200.

Wignall P.B., (1994): Black shales: Oxford University Press.

Williams G.L., Brinkhuis H., Pearce M.A., Fensome R.A. \& Weegink J.W. (2004): Southern Ocean and global dinoflagellate cyst events compared: index events for the Late Cretaceous-Neogene. Proceedings of the Ocean Drilling Program (pp. 1-98).

Wilson G. (1971): Observations on European Late Cretaceous Dinoflagellae Cysts. Proceedings II Planktonic Conference (pp. 1259-1275). Rome.

Yepes O. (2001): Maastrichtian-danian dinoflagellate cyst biostratigraphy and biogeography from two equatorial sections in Colombia and Venezuela. - Palynology 25(1): 217-249.

Zouhri S., Gingerich P.D., Elboudali N., Sebti S., Noubhani A., Rahali M. \& Meslouh S. (2014): New marine mammal faunas (Cetacea and Sirenia) and sea level change in the Samlat Formation, Upper Eocene, near Ad-Dakhla in southwestern Morocco. - Comptes Rendus 13(7): 599-610.

Zouhri S., Khalloufi B., Bourdon E., De Lapparent, De Broin F., Rage J.C., M'Haïdrat L., Gingerich P.D.(2018): Marine vertebrate fauna from the late Eocene Samlat Formation of Ad-Dakhla, southwestern Morocco. - Geological Magazine 155(7): 1596-1620. 
Authors' addresses: Amine Bouwafoud, Abdelmajid Benbouziane, Touria Hssaida \& Mustapha Mouflih, Hassan II University of Casablanca, Faculty of Sciences, Dynamic of Sedimentary Basins and Geological Correlations Laboratory, Av Driss El Harti, B.P 7955, Sidi Othmane, Casablanca, Morocco.

* Corresponding author: amine.bouwafoud-etu@etu.univh2c.ma 